\title{
Gender diversity and earnings management: the case of female directors with financial background
}

\author{
Alaa Mansour Zalata ${ }^{1,2}$ D . Collins G. Ntim ${ }^{1}$ - Mostafa Hussien Alsohagy ${ }^{3,4}$. \\ John Malagila ${ }^{1}$
}

Accepted: 18 May 2021 / Published online: 24 June 2021

(c) The Author(s) 2021

\begin{abstract}
Past evidence generally suggests that the presence of female directors on corporate boards tends to improve earnings quality due to these directors' superior monitoring abilities. However, it is not clear which characteristics and skills of female directors drive such abilities. In this paper, we focus on the financial background of female directors, an area which remains largely unexplored in existing literature. The results show that the participation of female directors with relevant financial background improves earnings quality more than the participation of female directors without such background. In addition, our findings suggest that only female directors possessing relevant financial background and having fewer outside directorships are able to mitigate earnings management and therefore overcommitting expert female directors with more outside directorships would diminish their monitoring ability. We did not find any evidence suggesting that female directors without relevant financial background are able to mitigate earnings management, irrespective of their outside directorships or tenure. We interpret our findings within a theoretical framework that draws on a number of economic and social theories. The results are generally robust after controlling for potential endogeneity problems.
\end{abstract}

Keywords Earnings management $\cdot$ Female directors $\cdot$ Financial expertise $\cdot$ Economic versus social theories

JEL Classification M41 · G34 · J16

Alaa Mansour Zalata

a.zalata@soton.ac.uk

1 Centre for Research in Accounting, Accountability and Governance, Southampton Business

School, University of Southampton, Southampton SO17 1BJ, UK

2 Department of Accounting, Faculty of Commerce, Mansoura University, Mansoura, Egypt

3 Westminster Business School, University of Westminster, London NW1 5LS, UK

4 Department of Accounting, Faculty of Commerce, Sohag University, Sohag, Egypt 


\section{Introduction}

The findings of past studies generally suggest that female directors tend to have a positive effect on a number of corporate outcomes, performance and stock price informativeness (Carter et al. 2003; Gul et al. 2011, 2013; Srinidhi et al. 2011; Kirsch 2018). However, the precise channels through which female directors are able to improve shareholder value in corporate boardrooms are not clear to date (Adams and Ferreira 2009). The central objective of this study, therefore, is to investigate whether it is the specialist skills and professional expertise (in this case, the financial background) of female directors that is associated with less earnings management rather than their gender per se, or otherwise.

Meanwhile, gender diversity has received growing attention throughout the last decade and, in general, there is a global call for the presence of women on corporate boards as a means of improving corporate decision-making and governance (Adams and Ferreira 2009; Cumming et al. 2015; Nguyen et al. 2020). Some countries have initiated a spate of legislative changes requiring a predetermined representation of female directors on corporate boards (Terjesen et al. 2009; Terjesen and Sealy 2016). For instance, Norway requires $40 \%$ of women's representation on corporate boards, with penalties for non-compliance. Following this, Spain and Sweden have considered female representation on corporate boards of $40 \%$ and $25 \%$, respectively and, consequently, the EU recently proposed women's board representation of $25 \%$ for large listed firms (Terjesen et al. 2009; Terjesen and Sealy 2016). A number of other developed and developing countries, such as Australia, Brazil, Canada and India, amongst others, have adopted or proposed similar quotas for women (Khlif and Achek 2017; Kirsch 2018) and, in the US, there has been a growing presence of female directors over the last two decades, although the appointment of female directors is still voluntary (Catalyst Group 2004).

The appointment of female directors is not only of great interest to policy-makers, politicians and regulatory authorities, but also to management, finance and accounting researchers. In addition, the appointment of women to corporate boards is perceived to be ethically appropriate and socially responsible corporate behavior (Owhoso 2002). On the other hand-and constituting the focus of our study-is that extant research shows that women have different characteristics and skills compared to men (e.g., more vigilant and risk-averse, cautious, conservative, fair, independent, objective and responsible) which place them in a better position to intensely monitor executives compared with the position of male directors (Daily and Dalton 2003; Rose 2007; Adams and Ferreira 2009; Bear et al. 2010; Gul et al. 2011; Srinidhi et al. 2011). In this case, we argue that female directors are not only more likely to challenge managerial opportunism, but also will be better at doing so than their male counterparts (Valenti 2008; Labelle et al. 2010; Sun et al. 2011; Capezio and Mavisakalyan 2016; Lara et al. 2017).

Indeed, the results of a few studies indicate that female directors tend to have a positive influence on a number of corporate outcomes, such as earnings management and performance (Carter et al. 2003; Gul et al. 2011; Kirsch 2018; Nguyen et al. 2020; Zalata et al. 2019a, b). Nevertheless, earnings management is an important issue that has long plagued corporations, and continues to pose major concerns for the broader society. A priori and due to their superior monitoring abilities (based on the predictions of economic theories), we expect that the presence of female directors on audit committees to restrain earnings management and improve the overall earnings quality. Meanwhile, the relationship between female directors and earnings management is a 
relatively under-examined issue and the results of the few studies that have attempted to address this question are generally inconclusive (e.g., Srinidhi et al. 2011; Sun et al. 2011; Lara et al. 2017).

While these studies examined whether the participation of female directors is associated with earnings management, they assumed that women are a homogeneous group and have not delved into their intra-differences. One of these differences is their financial background and, therefore, our study goes beyond mere female participation in the audit committees to argue that the association between female directors and earnings management might be largely contingent on their financial background. ${ }^{1}$ Arguably, improving financial reporting quality is partially dependent on directors' financial background (Li et al. 2012). Theoretically (based on economic and social predictions), while female directors might have strong motivation to constrain opportunistic actions, we argue that they may fail to do so effectively because they may lack the technical financial background required for overseeing the preparation of firms' financial reports, and in conducting in-depth discussions with managers or external auditors.

Whilst affirmative governance reforms around the world seem to be moving towards allocating more seats to female directors (Gul et al. 2013), they, surprisingly, are relatively silent about female directors' financial background. Consequently, we aim to shed light on an important policy question of whether it is merely female directors' presence per se on audit committees or their professional expertise and skills (i.e., financial background) that matters. We, thereby, aim to provide new insights that might encourage regulators to go beyond gender quotas and prioritize the recruitment of females with a financial background.

Using a sample of US firms, we found evidence that the participation of female directors on audit committees is associated with less earnings management. Furthermore, our additional analysis suggests that this finding is mainly driven by female directors with financial background. However, on average, we did not find evidence that female directors without financial background play significant role in mitigating earnings management. Interestingly, our supplementary analysis suggests that there are other factors that influence female directors, including their firm-related experience (tenure) and their outside directorships. We found that holding at least three other outside directorships (busy directors) tends to have a negative impact on the effectiveness of female directors with financial background. In particular, we found that busy female directors possessing relevant financial background are less likely to constrain earnings management than their rivals with a maximum of two other outside directorships. In addition, while we find that female directors with either long or short tenure mitigate earnings management, this finding is more pronounced with long-tenure female directors possessing relevant financial background. That is, it seems that long-tenured female directors with financial expertise are better able to maintain their independent judgment over time and less likely to develop professional affinity with their management team. Finally, we found no evidence suggesting that female directors without financial background are able to mitigate earnings management, irrespective of their

\footnotetext{
1 We focus on female directors on the audit committees for two main reasons. First, with the goal of improving earnings quality, the Sarbanes-Oxley Act of 2002 (SOX) stressed the importance of having financially experienced audit committee members. Second, since audit committee members, are directly responsible for monitoring the integrity of financial statements, comparing female directors with and without financial background on the board (irrespective of their participation on the audit committees) might bias the results as some females without financial background on the board have no role in monitoring financial reporting integrity.
} 
outside directorships and tenure. We interpret our findings within a theoretical framework that draws on a number of economic and social theories.

This study contributes to the extant research in a number of ways. First, it provides new insights on the crucial policy debate relating to board gender diversity and earnings management. While extant literature suggests that the participation of female directors within boardrooms is associated with less earnings management, our analysis extends this literature by documenting that improved earnings quality can be better achieved if female directors have financial background. We hope that our findings will serve as a motivation for boards of directors to pay more nuanced consideration to appointing female directors with financial background in order to create value for their shareholders. Second, our extra analysis highlights the importance of other outside directorships that female directors with financial background would mutually hold. In particular, our findings suggest that holding more outside directorships would impact negatively on the ability of female directors possessing relevant financial background in constraining earnings management. That is, firms might give a preference to female directors with less outside directorships and particular attention might be given to busy female directors. Finally, our findings have an important implication for regulators as well. They suggest that the mere presence of female directors per se on corporate boards does not necessarily improve firms' earnings quality; instead, it demonstrates that firms with female directors who have financial background exhibit better earnings quality. This suggests that recent legislative changes requiring blanket female director quotas within boardrooms should go beyond this and incorporate and focus more on female directors with reasonable financial background.

The rest of this paper is organized as follows. Section 2 discusses theoretical framework, reviews the literature on gender diversity and outlines our research question. Section 3 discusses the research design, and data. Sections 4, 5 and 6 present and discuss the empirical findings. Section 7 concludes the paper.

\section{Theoretical framework and literature review}

\subsection{Theoretical framework}

Recently, the number of female directors has been steadily increasing, although it is still relatively low, and currently most firms do have female directors on their boards (Williams 2003; Gul et al. 2011). Arguably, the appointment of female directors is likely to enhance board independence and improve the shareholder value in many ways. It is widely accepted that gender differences do exist and, given this, economic (e.g., agency, behavioral, economics, organizational and psychology theories) and social (e.g., ethical, moral development and social role theories) theoretical literature provides persuasive evidence that females might have better skills than their male counterparts. For example, and from the perspectives of agency and organizational theories (Lara et al. 2017), the appointment of female directors would facilitate more informed decisions, enhance the decision-making process, and improve communication among board members (Daily and Dalton 2003; Rose 2007; Bear et al. 2010).

In addition, and from moral development (Kohlberg 1984) and social role theory view (Chizema et al. 2015), female directors can enhance the depth and breadth of discussion and deliberations, particularly those related to challenging issues (Stephenson 2004; Huse and Solberg 2006; Srinidhi et al. 2011). For example, Adams and Ferreira (2009) argue 
that because female directors do not belong to 'old-boy' networks, they are more likely to provide greater oversight, monitoring and independent thinking expected from independent directors. Similarly, and based on behavioral, organizational and psychological theories, female directors tend to exhibit better board attendance, adopt strong monitoring positions, and demand greater accountability from CEOs for bad performance (Gul et al. 2011). This close monitoring would not only help in reducing the information asymmetry at the board level, but also encourage more public disclosure by curbing managers' use of insider information to their own benefit (Gul et al. 2011; Srinidhi et al. 2011), which would constrain managers' opportunism.

Another theory (drawing insights from behavioral, economic and psychology theories) underpinning female directors' monitoring efficacy is that female directors are more conservative and risk-averse than their male counterparts are (Powell and Ansic 1997; Martin et al. 2009; Huang and Kisgen 2013; Faccio et al. 2015; Liu et al. 2016; Harris et al. 2019; Kao et al. 2020; Zalata et al. 2019a; Tang et al. 2020) and, therefore, they are less likely to allow managerial opportunism for fear of being caught. In addition, based on social (e.g., ethical, moral development and social role theories) theories-female directors are more ethically sensitive than male directors (i.e., Owhoso 2002; Simga-Mugan et al. 2005; Lund 2008; Ibrahim et al. 2009; Wang and Clift 2009; Sarin and Wieland 2016) and, thus, they are less likely to be tolerant of managerial opportunism than male directors are. Finally, female directors tend to confer greater importance on 'communal values', such as altruism, benevolence, caring, communication, consensus building, empathy, generosity and trust, while maintaining good relationship with others in general (Kohlberg 1984; Eagly 2009). By contrast, male directors have been shown to prefer 'agentic values', such as achievement, confidence, control and power (Huang and Kisgen 2013; Chizema et al. 2015). Meanwhile in Adams and Ferreira's (2007) theory of friendly boards, directors who are more articulate, caring, empathetic and trustworthy are more likely to be effective at gaining the trust of executives and, therefore, more successful at performing their strategic counselling and advisory roles. Consequently, female directors' superior possession of these 'soft' skills (e.g., caring, communication and trustworthy) also implies that their ability to perform their role will be better than male directors.

\subsection{Literature review}

Extant research already supports the fact that female directors may have superior monitoring ability compared with male directors and firms with female representatives do outperform their rivals (e.g., Carter et al. 2003; Erhardt et al. 2003; Adams and Ferreira, 2004, 2009; Kao et al. 2020). Nevertheless, there is a dearth of studies examining the influence of gender-diversity on earnings and accounting quality. For instance, Gul et al. (2011) suggest that female directors enhance the information environment. Also, Gul et al. (2013) find that gender diversified boards are associated with accurate analysts' forecasts. For earnings management, two recent studies provide inconclusive findings. While Sun et al. (2011) find that gender diversified audit committees have no impact on constraining earnings management, Srinidhi et al. (2011) find that firms with women representatives on the audit committee exhibit higher earnings quality. Lara et al. (2017) show that female directors only mitigate earnings management in firms that discriminate against women's participation, while this relationship disappears in other firms. Zalata et al. (2019b) suggest that only female directors playing monitoring role improve earnings quality. Finally, focusing on blatant cases of manipulation, Cumming 
et al. (2015) find that the presence of female directors on a sample of Chinese corporate boards helped reduces the probability of fraud.

So far, these studies assume that all female directors are able to constrain managers' opportunistic behaviors. However, one problem such studies share is the ambiguity of the explanations offered as to why female directors mitigate earnings management. Gender studies are often criticized because such observed earnings quality might be attributed to other unobservable factors, such as knowledge disparities (Francis et al. 2014). Nevertheless, an unresolved research question is whether gender per se underpins why female directors are efficient monitors and, therefore, mitigate earnings management. Alternatively, this should be complemented by financial background if we really hope to garner the benefits of female directors.

For directors to be efficient monitors of managers, Beekes et al. (2004) argued that they should have a sufficient monitoring incentive and understand the consequences of financial reporting decisions. Economic and social theory, on the other hand, suggests that while female directors have sufficient monitoring incentives, they would understand the outcomes of financial reporting decisions better if they have a financial background. This is because the financial background enables directors to deal with the complexity of financial reporting, understand the financial reporting decisions, understand auditors' judgment, and support auditor in auditors-management disputes (Kalbers and Fogarty 1993; DeZoort and Salterio 2001; Mangena and Pike 2005; Zhang et al. 2007; Li et al. 2012). Extant empirical literature shows, for example, that directors' efficacy is partially dependent on their experience (Faleye et al. 2018; Al Lawati et al. 2021), which plays a crucial role in constraining aggressive accounting practices. In essence, Xie et al. (2003), Abbott et al. (2004), Bedard et al. (2004), Dhaliwal et al. (2010), and Badolato et al. (2014) find that firms with more outside directors possessing relevant financial background are characterized by less earnings management and less probability of financial reporting restatement.

As such, the findings of the financial background literature raise a valid concern of whether it is the gender of audit committee members that matters or whether it is their financial background. This is an important and timely research question since many countries have imposed regulations on companies to allocate some board seats to female directors. However, these regulations do not require specific expertise of female directors. Among these, the most salient expertise in assuring effective monitoring is the ability to interpret the outcomes of firms' financial reporting decisions. In the meantime, it may be that extant regulations endorse firms to recruit female directors with limited experience just for legitimacy reasons and comply with current rules which, in turn, might undermine the value of female directors and jeopardize corporate governance improvements.

We acknowledge that, given the gender differences, female directors are better able to create value for shareholders than their male counterparts are. Nevertheless, despite the benefits of appointing female directors, the current study contends that not all of them would be able to constrain earnings management; instead, we argue that female directors with relevant financial background could play a more effective monitoring role in constraining managerial opportunism than other female directors would. That is, building on extant research, the current study aims to investigate whether it is gender per se that has an impact on earnings management. Alternatively, female directors serving on the audit committees should be equipped with the relevant financial background. It is essential to understand such an impact when evaluating the desirability of legislation focusing on female background. 


\section{Method and data}

\subsection{Emprical model}

To investigate whether female directors affect earnings management, we use discretionary accruals as a proxy for these practices. Discretionary accruals can be defined as the extent to which accruals embedded in earnings are opportunistically used by management (Jones 1991). In order to reach a measure for discretionary accruals $(D A C C)$, we draw on prior studies and use the performance-adjusted Jones (1991) model as follows,

$$
W C A_{i, t} / A T_{i, t-1}=\beta_{0}+\beta_{1} 1 / A T_{i, t-1}+\beta_{2} A d j \_S A L E S_{i, t} / A T_{i, t-1}+\beta_{3} R O A_{i, t}+\varepsilon_{i t},
$$

where WCA is working capital accruals measured as the (change in current assets-change in cash and short-term investment) - (change in current liabilities - change in the current portion of long-term debt). AT is total assets. Adj_SALES is change in sales less changes in accounts receivable, and $R O A$ is the return on assets measured as the net income before extraordinary items scaled by lagged assets. We then calculate the discretionary accrual $(D A C C)$ for each firm as the residuals from Eq. (1) estimated annually for each two-digit SIC industry with at least 20 observations. ${ }^{2}$ In addition, the following model is then used in testing our research question:

$$
\begin{aligned}
A B S \_D A C C= & \beta_{0}+\beta_{1} F E M E X+\beta_{2} F E M I N E X+\beta_{3} M A L E X \\
& +\beta_{4} A C S I Z E+\beta_{5} B I N D+\beta_{6} B I G 4 \\
& +\beta_{7} S I Z E+\beta_{8} L E V+\beta_{9} O C F+\beta_{10} R O A+\beta_{11} M B V \\
& +\beta_{12} L O S S+\beta_{13} L N O A+\beta_{14} T R E M,
\end{aligned}
$$

where $A B S \_D A C C$ is the absolute value of $D A C C$. FEMEX is the proportion of audit committee female directors with relevant financial background, whilst FEMINEX is the proportion of audit committee female directors without relevant financial background. We follow Armstrong et al. (2015) who define financial expert directors based on the definition provided by the ISS database, which is consistent with SOX and SEC definitions. In essence, we follow the ISS definition because Dhaliwal et al. (2010) and Hsu et al. (2018) highlight the importance of directors' diversified skills, as well as in order for our analysis to be consistent with SOX and SEC regulatory language. To test our research question, the current study focuses on the coefficients $\beta_{1}$, and $\beta_{2}$ and they are expected to be negative and significantly different. Although we focus on female directors with relevant financial background (FEMEX), one might argue that male directors with relevant financial background are also associated with the level of earnings management and, therefore, we control for male directors with such financial background (MELEX). In addition, we control for other observable corporate governance variables that might influence the level of earnings management. In particular, we control for audit committee size (ACSIZE) and percentage of independent directors $(I N D)$.

Extant research also suggests that external auditors influence firms' ability to manage their earnings, and therefore we control for external auditor quality $(B I G 4)$. We also control

\footnotetext{
${ }^{2}$ Our calculation for discretionary accruals starts by running model (1) at industry-year level and therefore we require at least 20 observations for each industry-year in order to ensure sufficient observations for the coefficients' estimations.
} 
Table 1 Descriptive statistics for the full sample

\begin{tabular}{lrrrrr}
\hline Variables & Mean & Median & SD & Q1 & Q3 \\
\hline ABS_DACC & 0.07 & 0.04 & 0.10 & 0.02 & 0.08 \\
FDIR & 0.12 & 0.00 & 0.17 & 0.00 & 0.25 \\
FEMEX & 0.05 & 0.00 & 0.12 & 0.00 & 0.00 \\
FEMINEX & 0.07 & 0.00 & 0.13 & 0.00 & 0.00 \\
MALEX & 0.44 & 0.33 & 0.31 & 0.25 & 0.67 \\
ACSIZE & 3.71 & 4.00 & 0.90 & 3.00 & 4.00 \\
IND & 0.79 & 0.80 & 0.11 & 0.71 & 0.88 \\
BIG4 & 0.92 & 1.00 & 0.26 & 1.00 & 1.00 \\
SIZE & 7.71 & 7.51 & 1.55 & 6.57 & 8.70 \\
LEV & 0.50 & 0.28 & 0.92 & 0.01 & 0.63 \\
OCF & 0.13 & 0.12 & 0.08 & 0.08 & 0.17 \\
ROA & 0.06 & 0.06 & 0.08 & 0.03 & 0.11 \\
MBV & 2.95 & 2.22 & 2.69 & 1.45 & 3.46 \\
LOSS & 0.14 & 0.00 & 0.35 & 0.00 & 0.00 \\
LNOA & 0.70 & 0.54 & 0.57 & 0.33 & 0.86 \\
TREM & -0.03 & -0.01 & 0.47 & -0.24 & 0.21 \\
\hline
\end{tabular}

All variables' definitions are given in "Appendix A"

for other firms' characteristics that might influence earnings management. In particular, we control firm size $(S I Z E)$, leverage $(L E V)$, operating cash flows $(O C F)$, return on assets $(R O A)$, market to book value $(M B V)$, last year net operating assets $(L N O A)$ and real earnings management (TREM). All variables are defined in "Appendix A".

\subsection{Sample}

Since financial background data became available on ISS (formerly RiskMetrics) from 2007, our sample starts from 2007 and runs to 2013. We obtain the required financial data from the annual Compustat File. Given the differences in financial reporting requirements between financial and non-financial sectors, reflecting extant research, we exclude financial firms from our sample. In addition, we exclude firms with missing financial data required to run our expectation models and calculate other control variables. Furthermore, we exclude non-financial industries with observations of less than 20 firm-year observations in order to avoid bias in estimating discretionary accruals and to ensure an adequate number of observations to run our expectation models. After obtaining measure of discretionary accruals, we merge our financial data with the corporate governance and financial expert data obtained from the ISS database and we exclude firms with missing corporate governance data. The final sample is 5398 firm-year observations. 
Table 2 Descriptive statistics comparing firms with at least one female director serving on the audit committee and firms with no female directors serving on the audit committee

\begin{tabular}{|c|c|c|c|c|c|c|c|c|}
\hline \multirow[t]{2}{*}{ Variables } & \multicolumn{3}{|c|}{$\begin{array}{l}\text { Firms with at least one female } \\
\text { director }(\mathrm{N}=2169)\end{array}$} & \multicolumn{3}{|c|}{$\begin{array}{l}\text { Firms with no female director } \\
(\mathrm{N}=3229)\end{array}$} & \multicolumn{2}{|c|}{$\begin{array}{l}\text { Test of difference } \\
\text { between means }\end{array}$} \\
\hline & Mean & Median & SD & Mean & Median & SD & t-statistic & $P$ value \\
\hline ABS_DACC & 0.06 & 0.04 & 0.10 & 0.07 & 0.04 & 0.11 & 3.4575 & 0.0005 \\
\hline MALEX & 0.36 & 0.33 & 0.25 & 0.50 & 0.33 & 0.33 & 15.7440 & 0.0000 \\
\hline ACSIZE & 4.06 & 4.00 & 0.96 & 3.47 & 3.00 & 0.78 & -24.6728 & 0.0000 \\
\hline IND & 0.81 & 0.83 & 0.10 & 0.77 & 0.80 & 0.11 & -12.8262 & 0.0000 \\
\hline BIG4 & 0.98 & 1.00 & 0.15 & 0.89 & 1.00 & 0.31 & -12.0368 & 0.0000 \\
\hline SIZE & 8.16 & 8.02 & 1.61 & 7.41 & 7.23 & 1.42 & -18.0510 & 0.0000 \\
\hline LEV & 0.63 & 0.39 & 1.05 & 0.41 & 0.21 & 0.81 & -8.7785 & 0.0000 \\
\hline $\mathrm{OCF}$ & 0.13 & 0.12 & 0.08 & 0.13 & 0.12 & 0.09 & 1.5659 & 0.1174 \\
\hline ROA & 0.07 & 0.06 & 0.08 & 0.06 & 0.06 & 0.09 & -0.9495 & 0.3424 \\
\hline MBV & 3.20 & 2.31 & 3.11 & 2.78 & 2.16 & 2.36 & -5.6798 & 0.0000 \\
\hline LOSS & 0.13 & 0.00 & 0.33 & 0.15 & 0.00 & 0.35 & 1.8307 & 0.0672 \\
\hline LNOA & 0.67 & 0.51 & 0.58 & 0.72 & 0.57 & 0.57 & 2.8978 & 0.0038 \\
\hline TREM & -0.02 & -0.01 & 0.47 & -0.03 & -0.01 & 0.48 & -1.0482 & 0.2946 \\
\hline
\end{tabular}

Column one reports the mean, median and standard deviation using a sample of firms with at least a female director serving on the audit committee, Column two reports the same statistics using a sample of firms with no female directors serving on the audit committee, and the last column reports the statistical differences between these two samples

All variables' definitions are given in "Appendix A"

\section{Results}

\subsection{Descriptive statistics}

We summarize the descriptive statistics for the full sample in Table 1. These show that female directors with relevant financial background represents, on average, $5 \%$ of audit committees members, while female directors without financial background represents $7 \%$, demonstrating insignificant differences in the representation of female directors both with/ out financial background on audit committees. In addition, we split our full sample into two groups based on the presence of at least one female director serving on the audit committee and report the descriptive statistics for these two groups in Table 2. These show that our sample comprises 2169 firm-year observations, or $40 \%$ of the full sample, with at least one female director serving on their audit committees. We delve into these firms in greater detail and find that almost $81 \%$ of these 2169 observations have only one female director serving on their audit committees. Therefore, it seems that female directors are still underrepresented on firms' audit committees and the time has come to call for new rules regulating the participation of female directors on audit committees, particularly those with a financial background. Table 2 shows that the mean of $A B S \_D A C C$ is 0.06 for firms with at 
Table 3 Descriptive statistics comparing firms with at least one female director with Financial Expertise Serving on the audit committee and firms with at least one Female Inexpert Directors Serving on the Audit Committee

\begin{tabular}{|c|c|c|c|c|c|c|c|c|}
\hline \multirow[t]{2}{*}{ Variables } & \multicolumn{3}{|c|}{$\begin{array}{l}\text { Firms with at least one female } \\
\text { director with relevant financial } \\
\text { background }(\mathrm{N}=1023)\end{array}$} & \multicolumn{3}{|c|}{$\begin{array}{l}\text { Firms with at least one female } \\
\text { inexpert and no female expert } \\
(\mathrm{N}=1146)\end{array}$} & \multicolumn{2}{|c|}{$\begin{array}{l}\text { Test of difference } \\
\text { between means }\end{array}$} \\
\hline & Mean & Median & SD & Mean & Median & $\mathrm{SD}$ & t-statistic & $P$ value \\
\hline ABS_DACC & 0.06 & 0.03 & 0.09 & 0.07 & 0.04 & 0.11 & 2.6830 & 0.0074 \\
\hline MALEX & 0.42 & 0.50 & 0.28 & 0.32 & 0.27 & 0.22 & -9.4480 & 0.0000 \\
\hline ACSIZE & 3.96 & 4.00 & 0.92 & 4.15 & 4.00 & 0.98 & 4.6030 & 0.0000 \\
\hline IND & 0.81 & 0.83 & 0.10 & 0.81 & 0.83 & 0.10 & 0.6167 & 0.5375 \\
\hline BIG4 & 0.98 & 1.00 & 0.12 & 0.97 & 1.00 & 0.17 & -2.1746 & 0.0298 \\
\hline SIZE & 8.35 & 8.29 & 1.56 & 7.99 & 7.82 & 1.64 & -5.2201 & 0.0000 \\
\hline LEV & 0.63 & 0.45 & 0.95 & 0.64 & 0.35 & 1.13 & 0.1098 & 0.9126 \\
\hline $\mathrm{OCF}$ & 0.13 & 0.12 & 0.08 & 0.13 & 0.12 & 0.08 & 0.4147 & 0.6784 \\
\hline ROA & 0.07 & 0.06 & 0.07 & 0.07 & 0.06 & 0.08 & -0.6159 & 0.538 \\
\hline MBV & 3.13 & 2.35 & 2.91 & 3.27 & 2.25 & 3.27 & 1.0636 & 0.2876 \\
\hline LOSS & 0.11 & 0.00 & 0.32 & 0.14 & 0.00 & 0.35 & 1.7590 & 0.0787 \\
\hline LNOA & 0.71 & 0.54 & 0.63 & 0.63 & 0.49 & 0.53 & -3.3299 & 0.0009 \\
\hline TREM & -0.05 & -0.03 & 0.46 & 0.01 & 0.01 & 0.47 & 2.6727 & 0.0076 \\
\hline
\end{tabular}

Column one reports the mean, median and standard deviation using a sample of firms with at least one female director having relevant financial background serving on the audit committee, Column two reports the same statistics using a sample of firms with at least one female director, but having no financial background serving on the audit committee, and last column reports the statistical differences between these two samples

All variables' definitions are given in "Appendix A"

least one female director compared with 0.07 for firms with male directors. Univariate tests of difference show that firms with male directors have significantly higher $A B S \_D A C C$ than those firms with at least one female director serving on a firm's audit committee. ${ }^{3}$ Also, the table shows significant differences between these two groups in terms of ACSIZE, IND, BIG4, SIZE, LEV, MBV, LOSS and LNOA.

Furthermore, we classify firms with at least one female representation on their audit committee into two groups based on the financial background of their female directors; namely, firms with at least one female director possessing relevant financial background ( $N 1023$ with $89 \%$ of them only having one FEMEX) and firms with at least one female director without relevant financial background $(N=1146)$. The descriptive statistics for these are reported in Table 3 and interestingly, consistent with our expectation, it shows that these two groups are significantly different in respect to $A B S \_D A C C$. Finally, Table 3 indicates that these two groups differ significantly in respect to ACSIZE, BIG4, SIZE, LOSS, LNOA and TREM.

We present Pearson Correlation Matrix between all variables used in our analysis in Table 4. In support of our expectation, it shows a negative association between $A B S \_D A C C$ and FEMEX, while the relationship between $A B S \_A D A C C$ and FEMINEX is negative, but insignificant. In addition, as reported in Table 4, it seems that our analysis does not suffer from any potential multicollinearity problems.

\footnotetext{
${ }^{3}$ We would like to thank an anonymous reviewer for drawing our attention to the fact that our large sample size might drive this significant difference.
} 


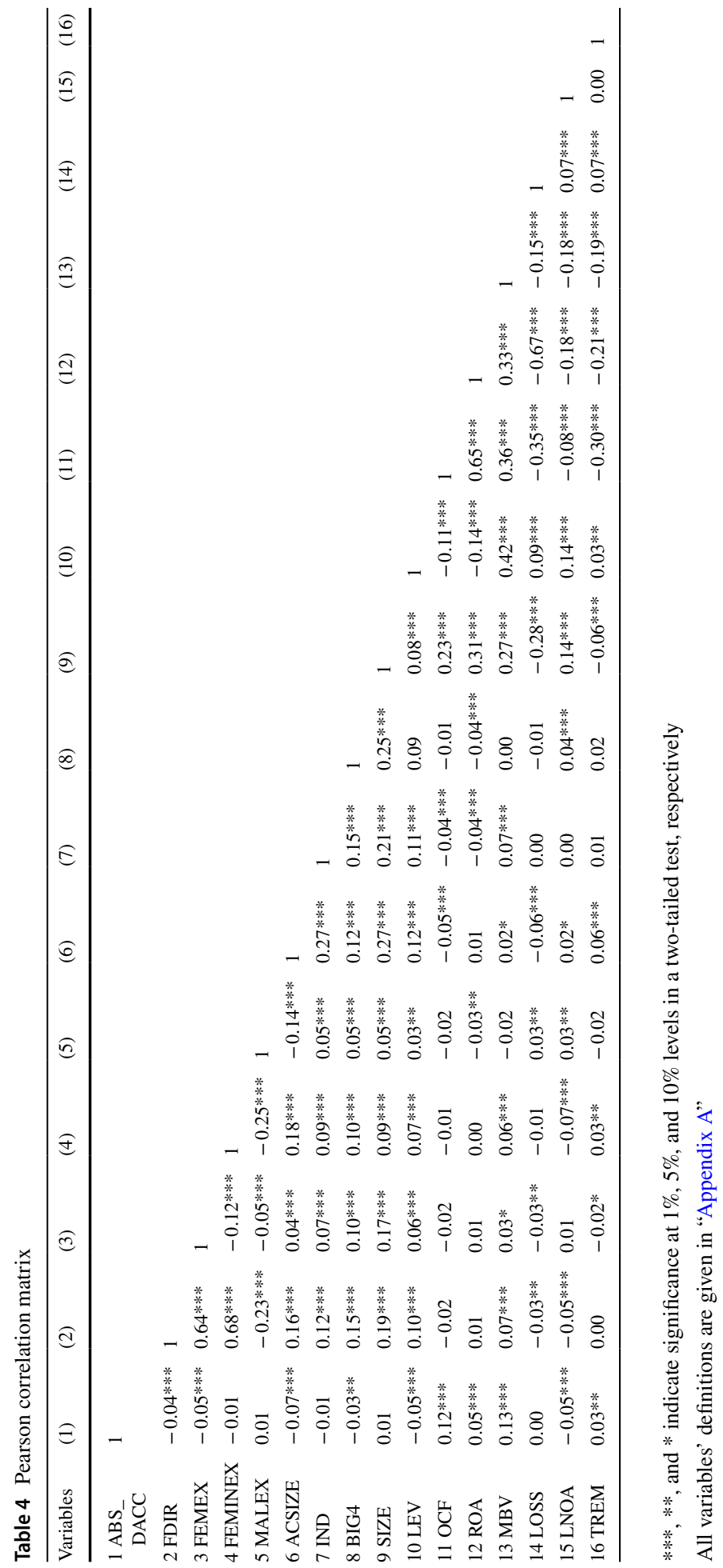


Table 5 Panel A: Regression estimates of discretionary accruals and female directors

\begin{tabular}{|c|c|c|c|c|}
\hline \multirow[t]{2}{*}{ Variables } & \multicolumn{2}{|l|}{ Column 1} & \multicolumn{2}{|l|}{ Column 2} \\
\hline & Coefficient & t-statistic & Coefficient & t-statistic \\
\hline FDIR & -0.022 & $-2.10^{* *}$ & & \\
\hline FEMEX & & & -0.051 & $-3.82 * * *$ \\
\hline FEMINEX & & & -0.010 & -0.69 \\
\hline MALEX & & & -0.007 & -1.15 \\
\hline ACSIZE & -0.005 & $-2.68 * * *$ & -0.006 & -3.04 \\
\hline IND & 0.007 & 0.44 & 0.008 & 0.51 \\
\hline BIG4 & -0.002 & -0.30 & -0.002 & -0.22 \\
\hline SIZE & -0.002 & $-1.81^{*}$ & -0.002 & -1.48 \\
\hline LEV & -0.012 & $-5.05^{* * *}$ & -0.011 & $-4.96 * * *$ \\
\hline $\mathrm{OCF}$ & 0.160 & $5.89 * * *$ & 0.158 & $5.82^{* * *}$ \\
\hline ROA & -0.052 & -1.38 & -0.051 & -1.36 \\
\hline MBV & 0.006 & $5.60 * * *$ & 0.006 & $5.53 * * *$ \\
\hline LOSS & 0.010 & 1.53 & 0.010 & 1.55 \\
\hline LNOA & -0.001 & -0.36 & -0.001 & -0.35 \\
\hline TREM & 0.019 & $4.33 * * *$ & 0.018 & $4.28 * * *$ \\
\hline _CONS & 0.064 & $4.53 * * *$ & 0.062 & $4.33 * * *$ \\
\hline Year fixed effect & YES & & YES & \\
\hline Adj_R $R^{2}$ & $9.51 \%$ & & $9.67 \%$ & \\
\hline F-statistic & 12.73 & & 11.53 & \\
\hline Number of Observations & 5398 & & 5398 & \\
\hline \multicolumn{5}{|c|}{ Panel B: Testing the significant differences between the coefficient on FEMEX, FEMINEX \& MALEX } \\
\hline FEMEX = FEMINEX & & & 0.041 & $\begin{array}{l}F=5.81 \\
\text { Prob }>F=0.0161\end{array}$ \\
\hline FEMEX $=$ MALEX & & & 0.044 & $\begin{array}{l}F=10.55 \\
\text { Prob }>F=0.0012\end{array}$ \\
\hline
\end{tabular}

Panel A contains regression estimates of discretionary accruals on female directors and other control variables. Under column 1, we regress discretionary accruals on all non-executive female directors serving on the audit committee and other control variables. Under column 2, we regress discretionary accruals on female directors with and without financial background serving on the audit committee and other control variables. In Panel B, we test the significant differences between the coefficients on FEMEX, FEMINEX \& MALEX

$* * *, * *$, and $*$ indicate significance at $1 \%, 5 \%$, and $10 \%$ levels in a two-tailed test, respectively

All variables' definitions are given in "Appendix A"

\subsection{Multivariate analysis}

Table 5 presents our regression analysis with $A B S \_D A C C$ as a dependent variable. In addition to investigating whether the financial background of female directors impacts their ability to mitigate earnings management, this study uses the current sample to confirm the results found in extant literature regarding the association between all types of female directors and $A B S \_D A C C$. Therefore, we run two alternative regressions with two different 
measures of female directors. In the first regression, similar to prior studies, we use a measure that captures all types of non-executive female directors $(F D I R)$ serving on audit committees, while in the second regression, we divide them into two groups. ${ }^{4}$ The first group includes female directors with relevant financial background (FEMEX), while the second group refers to female directors without financial background (FEMINEX).

The estimated coefficient on FDIR, as presented in Table 5 under column 1, is negative and significant at $5 \%$, thus supporting the proposition that firms with female directors are more likely to report higher earnings quality. Interestingly, as reported under column 2 of the Table 5, while the coefficient of female directors having relevant financial background $(F E M E X)$ is negative and significant at $1 \%$, there is insignificant relationship between $A B S \_D A C C$ and female directors without relevant financial background (FEMINEX). This result suggests that earnings management is lower in firms with female directors having relevant financial background. Furthermore, Panel B of Table 5 suggests that the coefficient on FEMEX is significantly lower than that of FEMINEX, and thereby suggesting that FEMEX has greater impact upon firms' earnings management than FEMINEX has. Interestingly, it seems that FEMEX has more profounded impect on earnings management than their male counterparts (MALEX) as reported in Panel B of Table 5.

Taken together, the results presented in Table 5 demonstrate that the financial background of female directors play a critical role in improving earnings quality. Particularly, these results provide considerable evidence suggesting that female directors with relevant financial background are associated with smaller discretionary accruals, thereby implying that these directors mitigate financial reporting opportunism in their firms.

So far, our analysis focuses on the impact of female directors serving on audit committees on accruals-based earnings management. Instead of using financial reporting judgements, managers might also inflate their earnings using other business decisions (real earnings management), such as offering excessive price discount or lenient credits, overproduction or cutting their discretionary expenses, such as R\&D (Roychowdhury 2006; Cohen et al. 2008; Cohen and Zarowin 2010; Francis et al. 2016; Liu 2020). Therefore, we go further and investigate whether the financial background of female members serving on the audit committees has an impact on these types of earnings management. One might argue that it is reasonable to extend our reported findings in Table 5 to real earnings management.

Nevertheless, audit committee members are responsible for monitoring the integrity of financial statements and for reviewing firms' financial reporting judgements and since real earnings management does not represent a violation of GAAP, it may not be subject to audit committee monitoring responsibilities. In addition, unlike accruals-based earnings management, real earnings management is related to routine business decisions undertaken throughout the year and arguably outside directors have less information about day-to-day operations (Osma 2008). That is, female directors on the audit committee have less scope to impact real earnings management. In order to investigate this proposition, we replace $A B S \_D A C C$ with TREM and its three components. We report this analysis in Table 6 and our findings suggest that both FEMEX and FEMINEX has less impact on real earnings management (earnings management using business decisions). As discussed above, we believe that this finding might be due to the fact that the audit committee members directly monitor financial reporting decision instead of business decisions, and therefore their value is more prominent with discretionary accruals. Given the dearth of this theoretical and

\footnotetext{
4 The rest of the analysis will use this measure.
} 


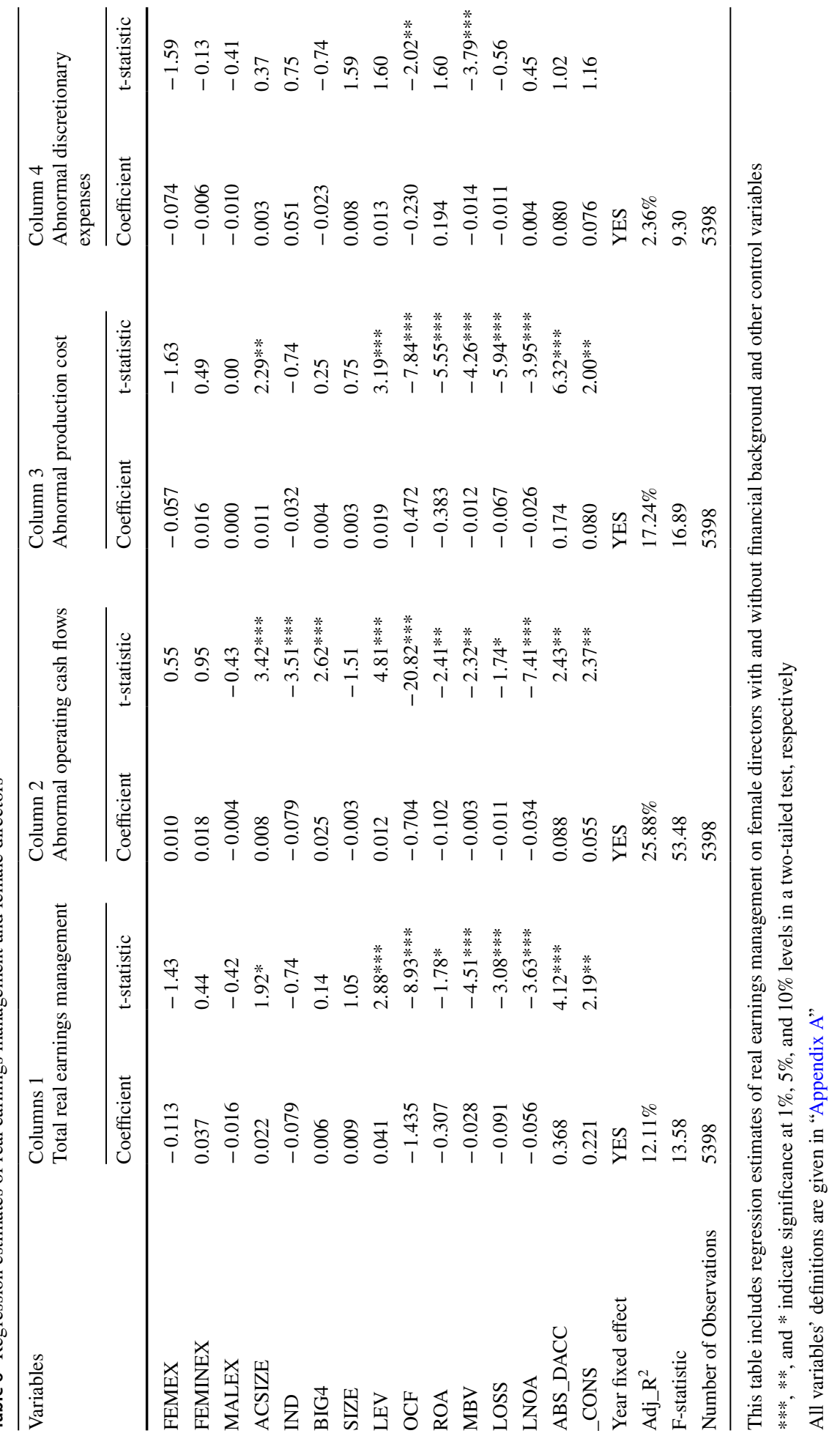


empirical support for the relationship between real earnings management and FEMEX and FEMINEX, our subsequent analyses will focus on discretionary accruals.

\section{Further analysis}

\subsection{Female directors' characteristics}

While our analysis suggests that female directors with financial background play a crucial role in ensuring the integrity of financial reports, we have assumed that female directors with relevant financial background are homogeneous and have so far ignored the fact that they should devote sufficient time to their firms' financial reporting issues. In this section, we go beyond their financial background and consider other factors that might influence their ability to oversight the financial reporting process. In particular, we focus on the outside directorships and tenure of female directors with relevant financial background.

\subsubsection{Outside directorships}

Arguably, holding outside directorships would improve directors' monitoring skills. In particular, this would enhance their experience and knowledge about corporate governance practices in other unaffiliated firms. That is, these directors represent important sources that facilitate the flow of strategic knowledge among boards and, therefore, enhance boardmonitoring effectiveness (Fama and Jensen 1983). In addition, these directors are more concerned about protecting their reputation and fear of any potential litigation and, consequently, directors with outside directorships are more likely to perform their duties diligently for fear of losing current and future outside directorships if their firms engaged in earnings management (Helland 2006; Sharma and Iselin 2012). On the other hand, directors with more outside directorships might devote insufficient time required to perform their duties at each firm, which in turn affect the quality of their oversight. The Professional Organization for Non-Executive Directors (PONED) recommends that directors should devote at least two days weekly to each firm that they serve on its board. That is, they should serve on a maximum of two other non-affiliated firms. The empirical findings of Beasley (1996) confirm the PONED recommendation/endorsement. However, it is not clear how the outside directorship affects the monitoring quality of female directors with relevant financial background.

Therefore, as a further analysis, we classify female directors with relevant financial background into two groups-directors who serve on at least three corporate boards (FEMEX_OUT) and directors who serve on less than three corporate boards (FEMEX LESS_OUT). Similarly, we classify female directors without such financial background in the same way (FEMINEX_OUT and FEMINEX_LESS_OUT). We report the findings of this analysis in Table 7 under column (1). Our findings show that while the coefficient on FEMEX_OUT is positive and significant at 10\%, the coefficient on FEMEX_LESS_OUT is negative and significant at $1 \%$, therefore suggesting that the outside directorships have a negative impact on female directors' ability to effectively constrain earnings management. Thus, while it is desirable to appoint female directors with the required financial background, firms might impose some restrictions on their outside directorships. In addition, 


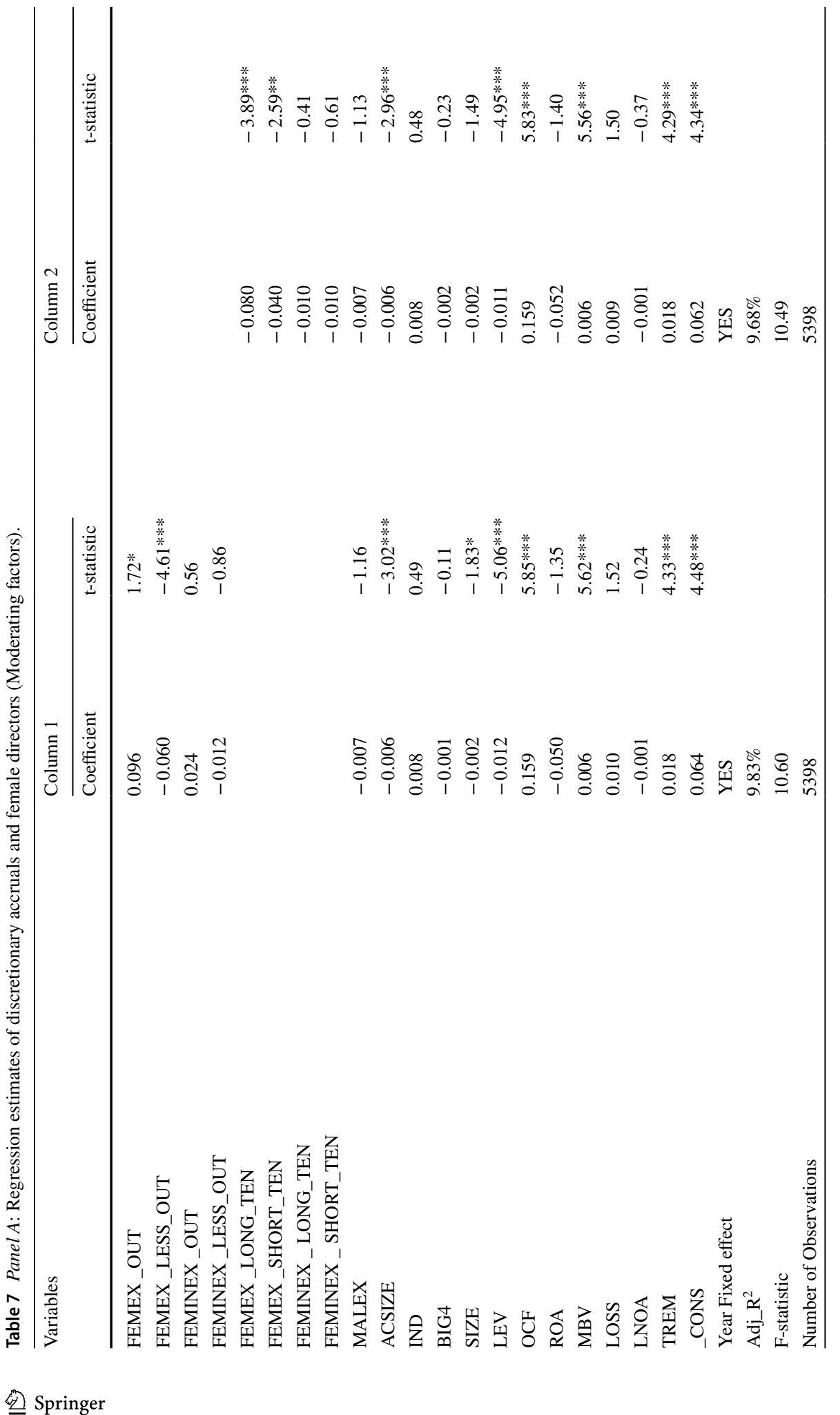




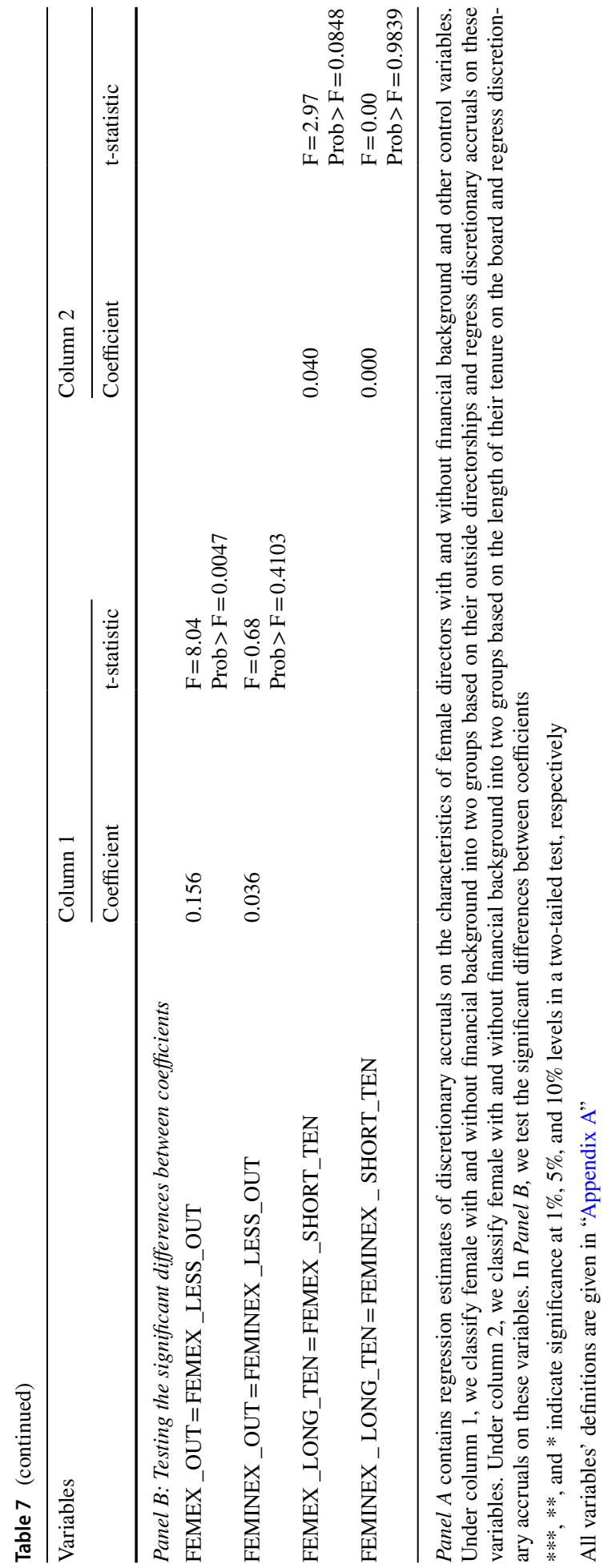


female directors without financial background (FEMINEX_OUT and FEMINEX_LESS_ $O U T$ ) are still not able to mitigate earnings management, irrespective of their outside directorships.

\subsubsection{Tenure}

Long serving period on the board and its committee may help directors to become an effective monitoring mechanism and protect shareholders' interests. This is because longer period serving on the committee will increase directors' knowledge and experience; therefore, they may become familiar with their organization's resources, with its methods of operations, technology, and culture (Singh and Harianto 1989; Yang and Krishnan 2005). Aldefer (1986) found that long-serving board members share a common understanding about their functions and companies' operations, while new directors need to wait before making any significant contribution in order to learn about their firms' organizational practices. In addition, during their tenure, these directors might receive some job training that would equip them with essential expertise, which can complement their financial background. In addition, short-tenure directors are more likely to be nominated and appointed by the current CEO and, therefore, these directors are more likely to have amiable and interdependent relationships with the current CEO, which might compromise their independence (Sun and Cahan 2009; Sun et al. 2009). This implies that long periods of serving on the board and its committees can improve the directors' accumulated experience and enhance their ability to challenge managers' financial reporting decisions. On the other hand, Beasley (1996) argues that new directors might be more independent from management and more vigilant, while directors who have served for long periods on the board might develop close ties with management and therefore new directors are more likely to be independent relative to directors with long tenure. However, Bedard et al (2004), Yang and Krishnan (2005) and Zalata and Roberts (2016) find that earnings management is less pronounced in firms with long-tenure directors. Consequently, we argue that as the period served on the board and its committees increase, the female directors with the required financial background may become more knowledgeable of firms' different practices and are therefore better able to deal with complicated financial reporting decisions, including earnings management. That is, we expect that the impact of female directors with relevant financial background to be more prominent when they serve on firms' board for a long period.

To investigate this conjecture, we classify female directors with relevant financial background using their tenure into two groups_-namely, short (FEMEX_SHORT_TEN) and long tenure (FEMEX_LONG_TEN). We classify them as having a short tenure if their tenure is eight years or less, and a long tenure if their tenure is more than 8 years. ${ }^{5}$ Similarly, we classify female directors without financial background in the same way (FEMINEX_SHORT_TEN and FEMINEX_LONG_TEN). The results of this analysis are reported in Table 7 under column (2). These results show that both long- and short-tenure female directors possessing relevant financial background (FEMEX_LONG_TEN and FEMEX_ SHORT_TEN) constrain earnings management. However, consistent with our expectation, Panel B shows that the coefficient on both long- and short-tenure female directors with relevant financial background is significantly different, suggesting that the impact of female

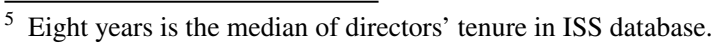


directors with relevant financial background is more pronounced when they have long tenure. In other words, it seems that long-tenure female directors with relevant financial background are less likely to develop affiliations with the management team and, therefore, are better able to maintain their independent judgment. Finally, female directors without such financial background (FEMINEX_SHORT_TEN and FEMINEX_LONG_TEN) are not able to mitigate earnings management, irrespective of their tenure.

\section{Robustness analysis}

\subsection{Controlling for endogeneity}

The results reported under the main analysis might be subject to potential self-selection bias if earnings management and female directors are endogenously determined, and thus any conclusion drawn from our model could be misleading. Therefore, to deal with any potential endogeneity problems, we use three well known methods: (i) the two-stage least squares $(2 S L S)$, (ii) the two-stage Heckman model, and (iii) propensity score matching.

First, when using $2 S L S$ method, we should first find relevant instrumental variables. In essence, under this approach, we use two instrumental variables that do not influence earning management, but might affect our main independent variables (FEMEX and FEMINEX). Following Srinidhi et al. (2011), our first instrument is the percentage of female directors within the industry. Our second instrument is female directors with financial background to male directors with financial background participation ratio in the industry where the firm operates. If this ratio is high, firms would have a large pool of good female directors possessing relevant financial background from which they can choose the best candidates for their board. That is, the higher this ratio, the greater the participation of female directors with financial background.

The results of the $2 S L S$ analysis are reported in Table 8 and, as expected, the first-stage regression indicates that our instruments are significantly related to FEMEX and FEMINEX. In addition, the $F$-statistic value is higher than the recommended value of 10 and the F-Test of excluded instruments is 25.41 and 20.92, respectively. In addition, Cragg-Donald Wald F statistic is 69.643, which is higher than Stock-Yogo weak ID test critical values of 7.03 , and therefore suggests that our instruments are valid. Finally, the second-stage regression still shows that female directors with relevant financial background (FEMEX) are able to significantly mitigate earnings management. Interestingly, it shows that the coefficient on female directors without financial background (FEMINEX) becomes significant at 5\%, indicating, therefore, that both types of female directors might have the same directional impact on earnings management because both of them share some inherited soft skills, such as risk aversion and ethical behavior among others, which might enhance their behavior towards earnings quality. However, Panel B of Table 8 still shows a significant difference between the coefficients on FENEX and FEMINEX, therefore reinforcing the importance of female directors' financial background.

Second, the current study uses a two-stage model as developed by Heckman (1976) to address possible endogeneity problems. While in the first-stage model, we compute the inverse Mills ratio (MILLS), in the second stage, we add MILLS as an additional control variable in Eq. (2). More specifically, in the first stage, we run a probit model capturing the determinants of appointing female directors on the audit committee and these include firm size, firm age, return on assets, sales growth, Tobin's Q, annual stock return, and audit 
Table 8 Panel A: Regression estimates of discretionary accruals and female directors (Controlling for Endogeneity; 2SLS)

\begin{tabular}{|c|c|c|c|c|c|c|}
\hline \multirow[t]{2}{*}{ Variables } & \multicolumn{2}{|l|}{$\begin{array}{l}\text { Column } 1 \\
\text { First stage } \\
(\text { FEMEX) }\end{array}$} & \multicolumn{2}{|c|}{$\begin{array}{l}\text { Column } 2 \\
\text { First stage } \\
\text { (FEMINEX) }\end{array}$} & \multicolumn{2}{|c|}{$\begin{array}{l}\text { Column } 3 \\
\text { Second stage }\end{array}$} \\
\hline & Coefficient & t-statistic & Coefficient & t-statistic & Coefficient & Z-statistic \\
\hline $\begin{array}{l}\text { FEMALE_INDU- } \\
\text { TRY }\end{array}$ & -0.050 & -0.56 & 0.609 & $6.41 * * *$ & & \\
\hline$\underset{\mathrm{EX}}{\text { WO_EX_to_ME_ }}$ & 0.410 & $7.08 * * *$ & -0.190 & $-3.37 * * *$ & & \\
\hline FEMEX & & & & & -0.863 & $-5.90 * * *$ \\
\hline FEMINEX & & & & & -0.309 & $-2.14^{* *}$ \\
\hline MALEX & -0.069 & $-6.08 * * *$ & -0.103 & $-11.72 * * *$ & -0.097 & $-4.11^{* * *}$ \\
\hline ACSIZE & -0.010 & $-2.85^{* * *}$ & 0.013 & $3.93 * * *$ & -0.009 & $-2.17 * *$ \\
\hline IND & 0.037 & 1.31 & 0.056 & $2.02 * *$ & 0.046 & 1.41 \\
\hline BIG4 & 0.028 & $3.28 * * *$ & 0.035 & $4.53 * * *$ & 0.031 & $2.46 * *$ \\
\hline SIZE & 0.013 & $4.82 * * *$ & 0.004 & $1.86^{*}$ & 0.011 & $3.07 * * *$ \\
\hline LEV & 0.007 & $1.72 *$ & 0.006 & $1.79^{*}$ & -0.002 & -0.35 \\
\hline $\mathrm{OCF}$ & -0.034 & -0.85 & -0.023 & -0.60 & 0.110 & $2.52 * *$ \\
\hline ROA & -0.007 & -0.18 & -0.019 & -0.47 & -0.059 & -1.15 \\
\hline MBV & -0.002 & -1.03 & 0.000 & -0.17 & 0.004 & $2.15 * *$ \\
\hline LOSS & 0.002 & 0.19 & 0.007 & 0.92 & 0.011 & 1.12 \\
\hline LNOA & -0.004 & -0.68 & -0.013 & $-2.50 * *$ & -0.013 & $-1.98 * *$ \\
\hline TREM & -0.006 & -1.12 & 0.005 & 0.79 & 0.012 & $2.06 * *$ \\
\hline _CONS & -0.102 & $-3.95^{* * *}$ & -0.115 & $-4.36^{* * * *}$ & -0.039 & -1.16 \\
\hline Year Fixed effect & YES & & YES & & YES & \\
\hline Adj_R ${ }^{2}$ & $11.57 \%$ & & $12.58 \%$ & & $-70.81 \%$ & \\
\hline F-statistic & 17.04 & & 18.74 & & 9.63 & \\
\hline $\begin{array}{l}\text { F Test of excluded } \\
\text { instruments }\end{array}$ & 25.41 & & 20.92 & & & \\
\hline $\begin{array}{l}\text { Cragg-Donald Wald } \\
\text { F statistic }\end{array}$ & & & & & 69.643 & \\
\hline $\begin{array}{l}\text { Number of Observa- } \\
\text { tions }\end{array}$ & 5398 & & 5398 & & 5398 & \\
\hline \multicolumn{7}{|c|}{ Panel B: Testing the significant differences between the coefficient on FEMEX, FEMINEX \& MALEX } \\
\hline $\begin{array}{l}\text { FEMEX = FEM- } \\
\text { INEX }\end{array}$ & & & & & 0.554 & $\begin{array}{l}\operatorname{chi} 2=10.55 \\
\text { Prob }>\text { chi } 2=0.0012\end{array}$ \\
\hline FEMEX $=$ MALEX & & & & & 0.766 & $\begin{array}{l}\operatorname{chi} 2=33.36 \\
\text { Prob }>\text { chi } 2=0.0000\end{array}$ \\
\hline
\end{tabular}

Panel A: contains regression estimates of discretionary accruals on female directors with and without financial background and other control variables using 2SLS regression. Under column 1, we report regression estimates of the first stage using FEMEX as dependent variables and under column 2, we report regression estimates of the first stage using FEMINEX as a dependent variable. Under column 3, we report our second stage regression of discretionary accruals on female directors with and without financial background after correcting for potential endogeneity concerns. In Panel B, we test the significant differences between the coefficients on FEMEX, FEMINEX \& MALEX

$* * *, * *$, and $*$ indicate significance at $1 \%, 5 \%$, and $10 \%$ levels in a two-tailed test, respectively

All variables' definitions are given in "Appendix A" 


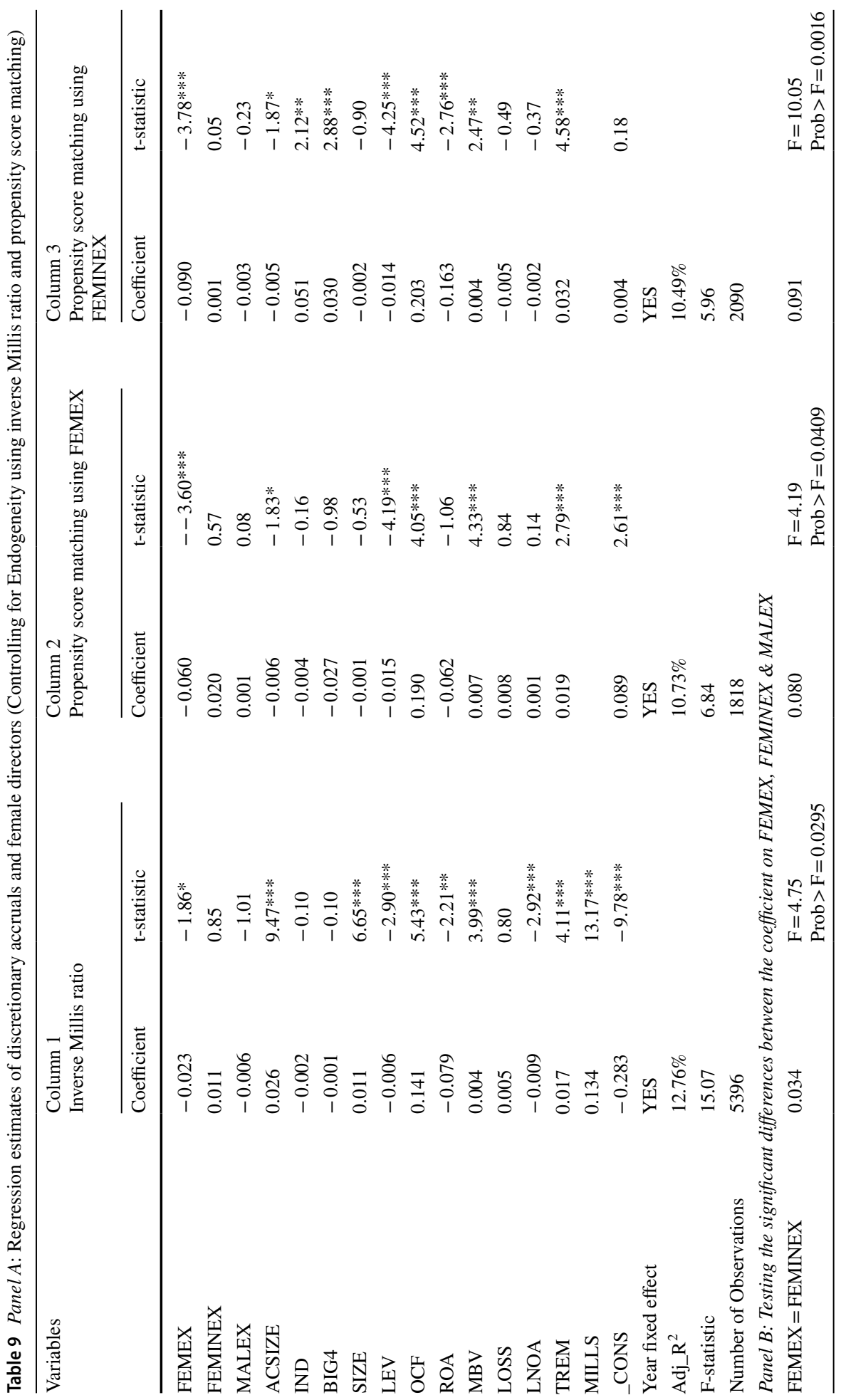




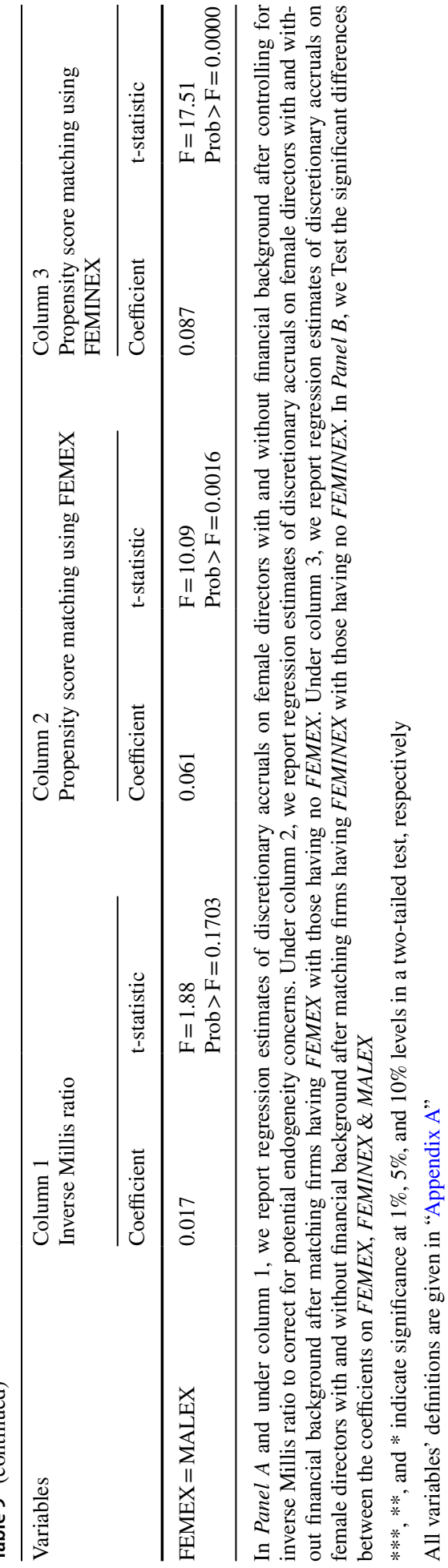


committee size. ${ }^{6}$ In addition, we control for the percentage of female directors within the industry and female directors with financial background to male directors with financial background participation ratio in the industry. We present the results of the second-stage regression in Table 9 under column 1, and these still suggest that female directors with relevant financial background (FEMEX) have more prominent impact on earnings management than female directors without such financial background (FEMINEX).

Finally, our last method to address potential endogeneity concerns is the propensity score-matching technique. We first transfer our main independent variables (FEMEX and FEMINEX) into dummy variables and then run a logit regression to predict the probability of appointing female director with financial expertise using the same variables included in Eq. (2). We use the predicted values obtained from this regression to match firms hiring FEMEX with others without FEMEX. Using these procedures, we find 909 matches for each observation with FEMEX. We then use both samples (firms with FEMEX and their matches) with total observations of 1,818 to re-estimate Eq. (2) and report this analysis in Table 9 under column 2. We follow the same procedures for each firm with FEMINEX and get matches of 1045 firm-year observations. Using both samples with total observations of 2090, we re-estimate Eq. (2) and report the findings in Table 9 under column 3. The results still offer support for our main conclusions and, therefore, our findings do not appear to be subject to significant endogeneity concerns.

\subsection{The presence of female directors with and without financial background}

Under the main analysis, female directors with relevant financial background and those without financial background have been measured as a continuous variable. However, when the percentages are used, a higher percentage might represent either a larger number of female directors or a smaller number of total directors with the same number of female directors. Therefore, as a robustness analysis, the mere presence of the female directors with relevant financial background is used. ${ }^{7}$ In particular, an indicator variable is set to 1 if the audit committee includes at least one female director with relevant financial background; and zero otherwise. Similarly, under this analysis, an indicator variable is set to 1 if the audit committee includes at least one female director without financial background; and zero otherwise. We report the findings of this analysis in Table 10 and they still support the main proposition of this study that female directors with relevant financial background are better able to maintain and improve earnings quality.

\footnotetext{
6 Firm age is measured as the number of years during which COMPUSTAT reports a firm's total assets since 1977. Sales growth is measured as change in sales scaled by last year sales. Tobin's Q is measured as (total assets - common equity + equity's market value) $\div$ total assets. Stock return is measured as stock price at year end minus stock price at the beginning of the year divided by stock price at the beginning of the year. Other variables are as defined in "Appendix A".

7 We would like to thank an anonymous reviewer for highlighting this concern.
} 


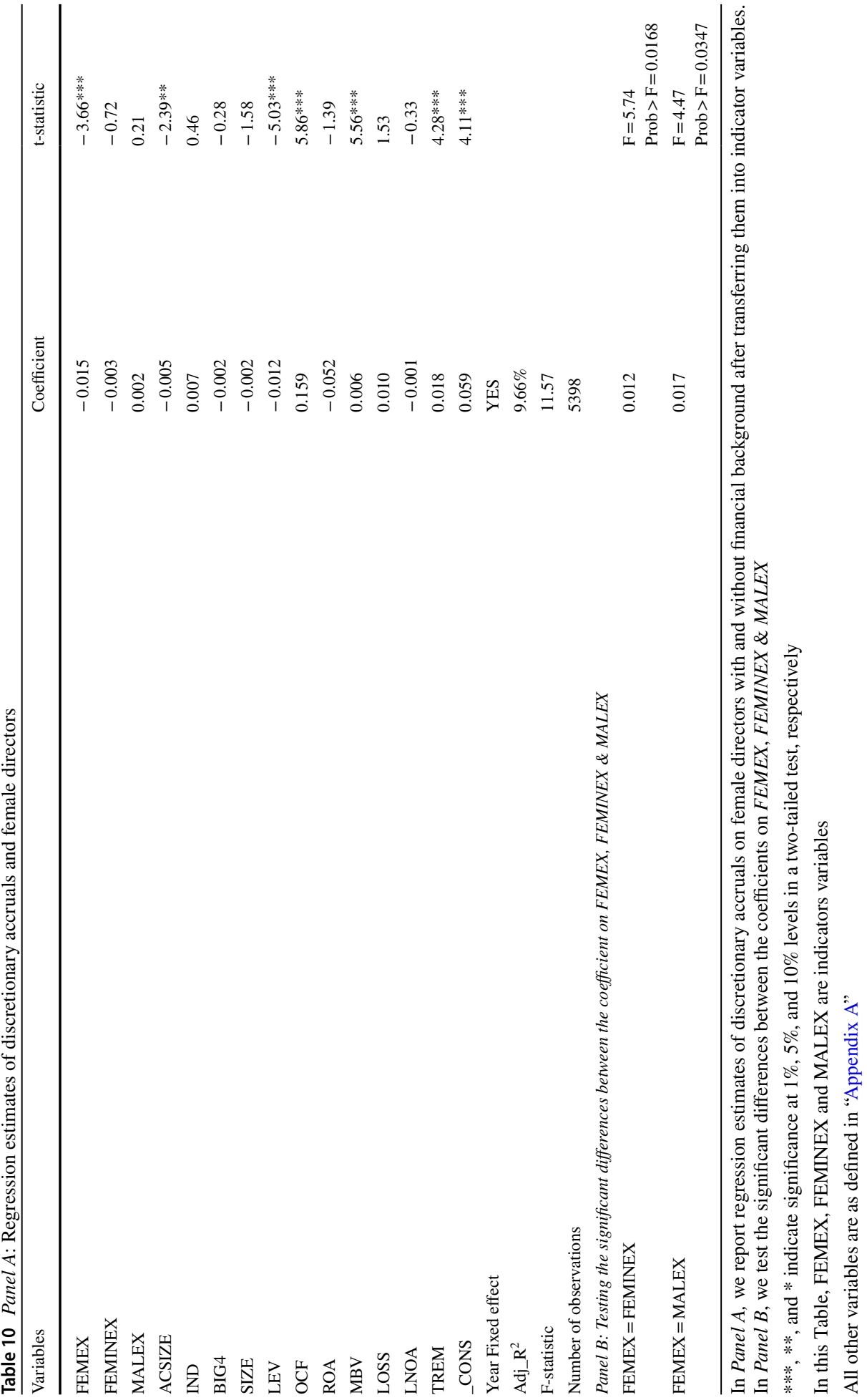


Table 11 Panel A: Regression estimates of discretionary accruals and female directors (Global financial crisis)

\begin{tabular}{|c|c|c|c|c|}
\hline \multirow[t]{2}{*}{ Variables } & \multicolumn{2}{|c|}{$\begin{array}{l}\text { Column } 1 \\
\text { Financial crisis time }\end{array}$} & \multicolumn{2}{|c|}{$\begin{array}{l}\text { Column } 2 \\
\text { Post financial crisis time }\end{array}$} \\
\hline & Coefficient & t-statistic & Coefficient & t-statistic \\
\hline FEMEX & -0.048 & $-2.95 * * *$ & -0.050 & $-3.11 * * *$ \\
\hline FEMINEX & -0.037 & $-2.84 * * *$ & 0.007 & 0.33 \\
\hline MALEX & -0.013 & -1.59 & -0.004 & -0.58 \\
\hline ACSIZE & -0.004 & -1.62 & -0.007 & $-2.78 * * *$ \\
\hline IND & 0.006 & 0.34 & 0.011 & 0.48 \\
\hline BIG4 & -0.009 & -1.10 & 0.003 & 0.35 \\
\hline SIZE & 0.000 & -0.15 & -0.003 & -1.63 \\
\hline LEV & -0.008 & $-3.65 * * *$ & -0.013 & $-4.28 * * *$ \\
\hline $\mathrm{OCF}$ & 0.121 & $4.30 * * *$ & 0.176 & $4.44 * * *$ \\
\hline ROA & -0.073 & $-1.96^{*}$ & -0.033 & -0.60 \\
\hline MBV & 0.004 & $4.02 * * *$ & 0.007 & $4.84 * * *$ \\
\hline LOSS & 0.004 & 0.56 & 0.014 & 1.60 \\
\hline LNOA & -0.011 & $-3.45^{* * *}$ & 0.004 & 1.00 \\
\hline TREM & 0.011 & $2.93 * * *$ & 0.023 & $3.62 * * *$ \\
\hline _CONS & 0.071 & $4.70 * * *$ & 0.050 & $2.64 * * *$ \\
\hline Year Fixed effect & YES & & YES & \\
\hline Adj_R ${ }^{2}$ & $7.77 \%$ & & $10.10 \%$ & \\
\hline F-statistic & 7.43 & & 11.38 & \\
\hline Number of Observations & 1882 & & 3516 & \\
\hline \multicolumn{5}{|c|}{ Panel B: Testing the significant differences between the coefficient on FEMEX, FEMINEX \& MALEX } \\
\hline FEMEX = FEMINEX & 0.011 & $\begin{array}{l}F=0.46 \\
\text { Prob }>F=0.4985\end{array}$ & 0.057 & $\begin{array}{l}F=6.36 \\
\text { Prob }>F=0.0118\end{array}$ \\
\hline FEMEX $=$ MALEX & 0.035 & $\begin{array}{l}F=4.14 \\
\text { Prob }>F=0.0423\end{array}$ & 0.046 & $\begin{array}{l}F=8.06 \\
\text { Prob }>F=0.0046\end{array}$ \\
\hline
\end{tabular}

Panel A: contains regressions estimates of discretionary accruals on female directors with and without relevant financial background and other control variables. Under column 1, we regress discretionary accruals on female directors with and without financial background using the financial crisis sample and under column 2, we regress discretionary accruals on female directors with and without financial background using the post financial crisis sample. In Panel $B$, we test the significant differences between the coefficients on FEMEX, FEMINEX \& MALEX

$* * *, * *$, and * indicate significance at $1 \%, 5 \%$, and $10 \%$ levels in a two-tailed test, respectively

All variables' definitions are given in "Appendix A"

\subsection{Subgroup analysis}

\subsubsection{Financial crisis}

Our sample covers the period 2007-2009, namely the financial crisis period. Arguably, crisis time is characterised by intense public scrutiny over financial reporting practices and shareholders are more concerned about firms' financial position (Filip and Raffournier 2014; Arthur et al. 2015). The financial crisis impacted negatively on investors' confidence and indeed, during this time, most investors were eager to sell their shares, which thereby 
led to sharp drop in share prices. This can engender some firms to respond by engaging in opaque financial reporting practices in order to mitigate the significant drop in share prices (Trombetta and Imperatore 2014). As such, if female directors, especially those with financial background can really protect shareholders' interests, then, arguably, the financial crisis period is the real time where their assurance over the financial reporting integrity might be most needed. Consequently, it is worth investigating whether there are significant differences between the impact of female directors during and after the global financial crisis.

In order to investigate this question, we split our sample into two periods, global financial crisis period (2007-2009) and post crisis period (2010-2013) and run Eq. 2 separately for these two samples. Results reported in Table 11 under column (2) demonstrate that, in the post financial crisis period, the results are qualitatively similar to our main analysis. Interestingly, during the financial crisis time, our findings reported in Table 11 under column (1) reveal that both types of female directors mitigate earnings management, and the significant difference between them disappear. Arguably, during the financial crisis period, companies' financial reporting practices were under intense scrutiny from regulators and the general public, and therefore, it seems that both types of female directors, as risk averse directors, were more likely to challenge firms' opportunistic practices.

\subsection{Meeting earnings benchmarks}

Our analysis focuses, so far, on all sample and ignores the possible managerial incentives behind earnings management. Arguably, firms are more likely to engage in earnings management to meet earnings benchmarks (e.g., avoid reporting earnings decrease) or to smooth their earnings. For instance, prospect theory suggests that users of financial information are more sensitive to negative numbers than positive numbers and therefore managers are motivated to report increase in their earnings. Indeed, extant research suggests that market participants and therefore, stock prices are sensitive to earnings benchmarks (Barth et al. 1999; Jiang 2008). In other words, stock market seems to reward (penalize) firms that meet/beat (miss) earnings benchmarks. As such, some firms might engage in earnings management to meet earnings benchmarks and therefore escape from being penalised by the market. One might argue that female directors might allow earnings management to avoid any potential costs (i.e., stock price downgrade). On the other hand, extant studies suggest that investors naively fixate on reported earnings and cannot see through earnings management (e.g., Sloan 1996; Xie 2001; Beneish and Vargus 2002). Since the value of female directors stems from the fact that they protect shareholders against managerial opportunism, we believe that if female directors really add value to their firms, then, they should spend much time and effort in a sample of firms that report earnings' increase in order to ensure that these firms report genuine earnings. Therefore, it is an empirical question of whether female directors, especially those with relevant financial background, tolerate or mitigate earnings management when it allows firms to meet earnings benchmark.

In order to investigate this question, we repeat our analysis using two subsamples; a sample of firms that reported earnings increase and a sample of other firms. We report the findings of this analysis in Table 12 under column 1 and it seems that female directors with relevant financial background does not tolerate earnings management even if it allows firms to avoid reporting earnings decrease. Furthermore, in order to provide sharper test of our proposition, instead of focusing on all firms that beat the benchmark regardless of 


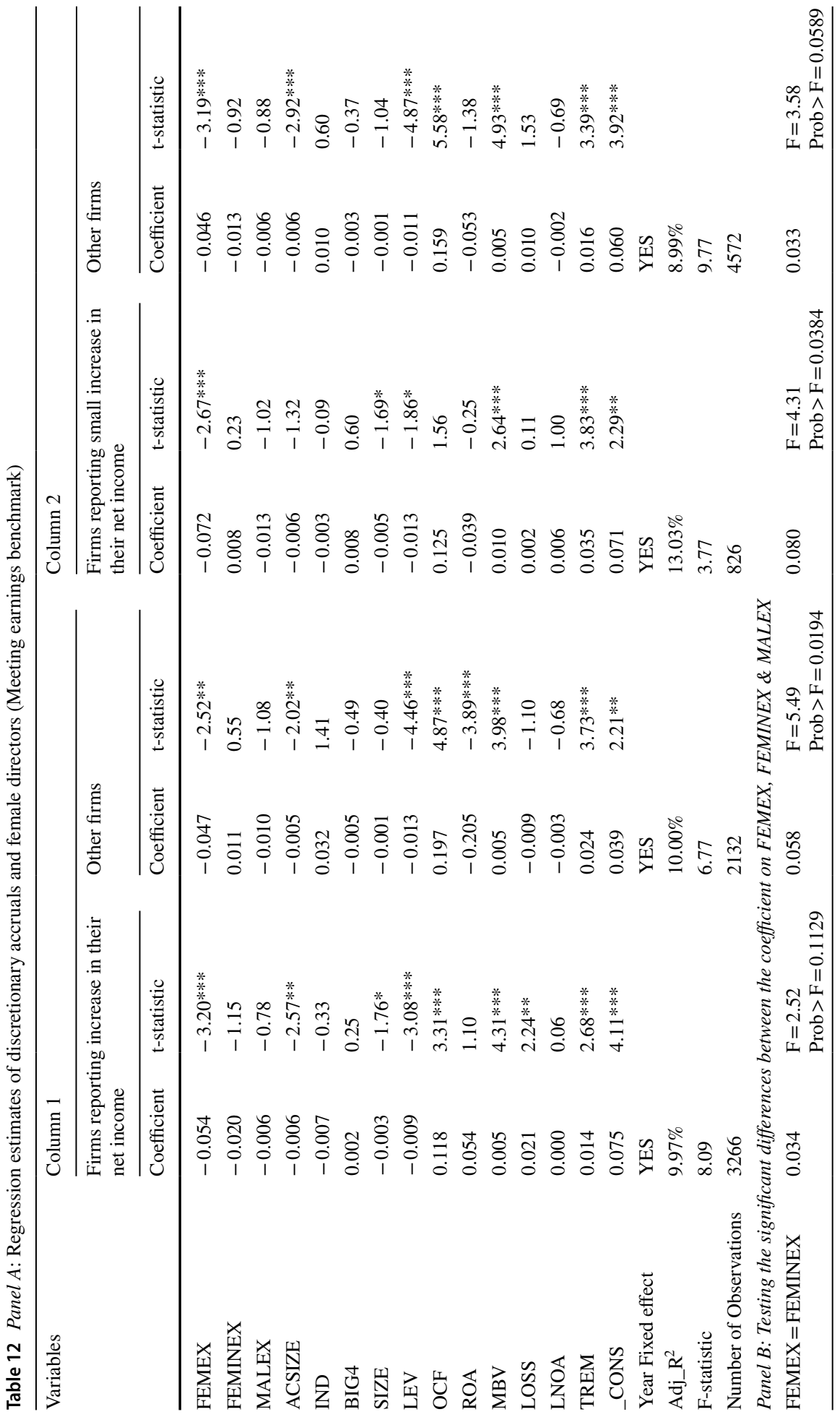




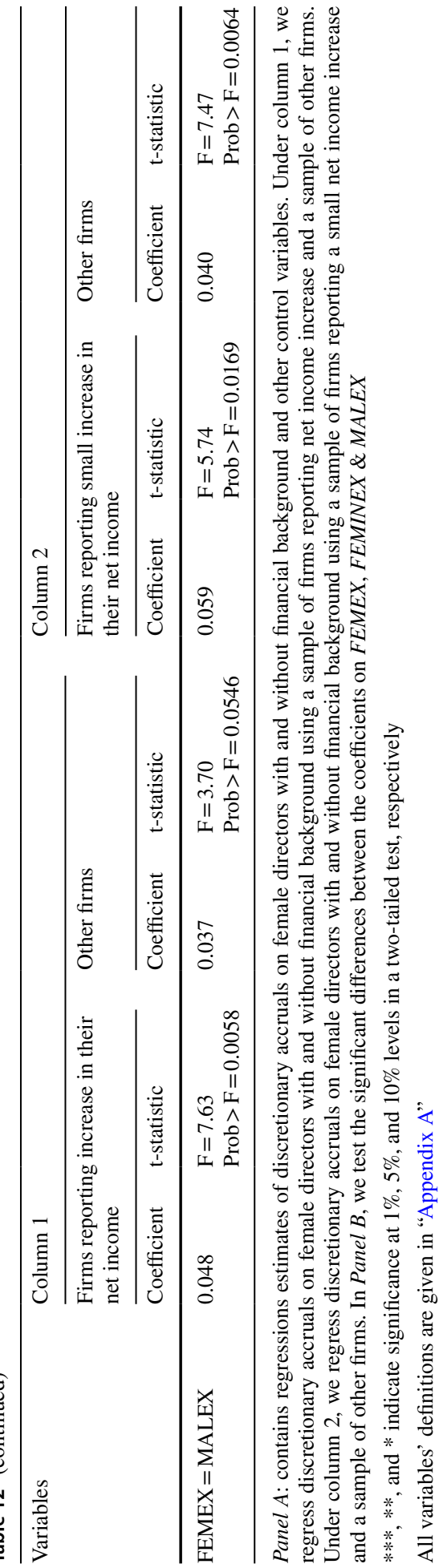


Table 13 Panel A: Regression estimates of discretionary accruals and female directors (Income smoothing)

\begin{tabular}{|c|c|c|c|c|}
\hline & \multicolumn{2}{|c|}{$\begin{array}{l}\text { Column } 1 \\
\text { Income smoothers }\end{array}$} & \multicolumn{2}{|l|}{$\begin{array}{l}\text { Column } 2 \\
\text { Other firms }\end{array}$} \\
\hline & Coefficient & t-statistic & Coefficient & t-statistic \\
\hline FEMEX & -0.074 & $-3.05 * * *$ & -0.045 & $-2.91 * * *$ \\
\hline FEMINEX & 0.000 & -0.02 & -0.011 & -0.73 \\
\hline MALEX & 0.004 & 0.30 & -0.011 & -1.56 \\
\hline ACSIZE & -0.004 & -1.03 & -0.006 & $-3.15^{* * *}$ \\
\hline IND & -0.013 & -0.46 & 0.019 & 1.03 \\
\hline BIG4 & -0.001 & -0.12 & -0.001 & -0.12 \\
\hline SIZE & -0.006 & $-2.10 * *$ & -0.001 & -0.86 \\
\hline LEV & -0.009 & $-1.81 *$ & -0.012 & $-4.57 * * *$ \\
\hline $\mathrm{OCF}$ & 0.116 & $2.26^{* *}$ & 0.178 & $5.63 * * *$ \\
\hline ROA & -0.002 & -0.03 & -0.061 & -1.54 \\
\hline MBV & 0.007 & $3.21 * * *$ & 0.005 & $4.70 * * *$ \\
\hline LOSS & -0.018 & -1.49 & 0.014 & $2.07 * *$ \\
\hline LNOA & 0.004 & 0.65 & -0.002 & -0.71 \\
\hline TREM & 0.033 & $4.14 * * *$ & 0.013 & $2.63 * * *$ \\
\hline _CONS & 0.100 & $3.55 * * *$ & 0.048 & $3.12 * * *$ \\
\hline Year fixed effect & YES & & YES & \\
\hline Adj_R ${ }^{2}$ & $12.29 \%$ & & $9.02 \%$ & \\
\hline F-statistic & 4.76 & & 9.46 & \\
\hline Number of observations & 1349 & & 4049 & \\
\hline \multicolumn{5}{|c|}{ Panel B: Testing the significant differences between the coefficient on FEMEX, FEMINEX \& MALEX } \\
\hline FEMEX = FEMINEX & 0.074 & $\begin{array}{l}F=4.94 \\
\text { Prob }>F=0.0266\end{array}$ & 0.034 & $\begin{array}{l}F=3.17 \\
\text { Prob }>F=0.0752\end{array}$ \\
\hline FEMEX = MALEX & 0.078 & $\begin{array}{l}F=8.22 \\
\text { Prob }>F=0.0043\end{array}$ & 0.034 & $\begin{array}{l}F=5.17 \\
\text { Prob }>F=0.0231\end{array}$ \\
\hline
\end{tabular}

Panel A: contains regressions estimates of discretionary accruals on female directors with and without financial background and other control variables. Under column 1, we regress discretionary accruals on female directors with and without financial background using a sample of firms that deemed to have smoothed their income and under column 2, we regress discretionary accruals on female directors with and without financial background using a sample of other firms. In Panel B, we test the significant differences between the coefficients on FEMEX, FEMINEX \& MALEX

$* * *, * *$, and $*$ indicate significance at $1 \%, 5 \%$, and $10 \%$ levels in a two-tailed test, respectively

All variables' definitions are given in "Appendix A"

the extent by which they did so, we focus on firms that narrowly beat the benchmarks (i.e., firms reporting increase in their net income scaled by lagged total assets between 0 and $1 \%$ ). We report this analysis in Table 12 under column 2 and the results are qualitatively similar.

\subsection{Income smoothing}

Managers might also use their discretion to smooth the fluctuations in their reported earnings (Beidleman 1973) and thereby help investors to better predict future earnings and 
probably reduce risk premium and cost of equity (Trueman and Titman 1988; Francis et al 2004; Tucker and Zarowin 2006). Given such benefits, one might argue that female directors serving on audit committees might allow managerial discretion that may be aimed at dampening possible fluctuations in earnings. On the other hand, earnings smoothing can indeed be costly. For instance, since managers' view of what may be considered to be acceptable financial reporting decisions can be different from regulators' view, Badertscher et al. (2012) and Baik et al (2020) noted that managerial discretion, even non-opportunistic discretion, might increase the probability of restatements and thereby litigation cost. As such, female directors may mitigate discretionary accruals even if it is conducted in order to smooth earnings, otherwise they may lose their reputation or probably their job if such practices were detected by regulators.

To investigate this proposition, we re-run Eq. 2 using two subsamples; income smoothers firms and other firms. We define the firm as income smoother if the ratio of its standard deviation of operating cash flows to its standard deviation of earnings before extraordinary items is in the highest quintile. ${ }^{8}$ Where cash flows and earnings are scaled by lagged total assets. Our results reported in Table 13 suggest that FEMEX mitigate discretionary accruals in both samples, demonstrating again that the value of these directors is not contingent of the motivation behind earnings management and indeed they mitigate discretionary accruals even when it is conducted to apparently smooth earnings.

\subsection{Other measures}

Under the main analysis, we use performance-adjusted discretionary accruals to get a proxy for earnings management. Extant studies also use a measure of earnings management based on Accruals Estimation Errors ( $A E E$ ) measured using the expectation model proposed by McNichols (2002) as follows,

$$
\begin{aligned}
W C A_{i, t} / A T_{i, t-1}= & \beta_{0}+\beta_{1} O C F_{i, t-1} / A T_{i, t-2}+\beta_{2} O C F_{i, t} \\
& +A T_{i, t-1}+\beta_{3} O C F_{i, t+1} / A T_{i, t}+\beta_{4} \Delta S A L E S_{i, t} / A T_{i, t-1}+\varepsilon_{i t},
\end{aligned}
$$

where $\mathrm{W} C A$ is working capital accruals and $O C F$ refers to cash flows from operations in years $t, t-1$, and $t+1 . \triangle S A L E S$ refers to the change in sales. The AEE for each firm is then estimated as the residuals from Eq. (3) run annually for each two-digit SIC industry with at least 20 observations. Using the absolute value of AEE as a measure of earnings quality, un-tabulated results still suggest that only female directors with financial background significantly mitigate earrings management.

\section{Conclusion}

The extant studies demonstrate that the presence of female directors on corporate boards can enhance earnings quality. However, they assume that female directors are homogeneous and, therefore, they have not delved into the interpersonal differences within female

\footnotetext{
${ }^{8}$ Arguably, having higher standard deviation of cash flows from operations than the standard deviation of earnings is consistent with income smoothing and therefore in order to provide sharper test we consider firms in the highest quintile to have used greater accounting discretion. We calculate rolling three-year standard deviation for each firm year observation.
} 
directors as a group. For instance, there might be differences between female directors not only in the stance they take towards managerial opportunism, but also in terms of their financial expertise (Sun et al. 2011). That is, while female directors might have a strong motivation to constrain managerial opportunism, they might lack the required financial expertise to perform this function. Therefore, drawing unique insights from a number of economic and social theories, and a large sample of US firms, this study examines whether gender per se has a real impact on earnings quality, or alternatively, whether it is the female directors' financial expertise that matters. Unlike prior studies, the current study splits female directors into two groups based on their financial background.

The results suggest that it is not gender difference that improves earnings quality; instead, it is female directors' financial background that seems to drive earnings quality. In particular, similar to prior studies, this study finds some evidence that high earnings quality is a characteristic of firms with a high proportion of female directors. However, when classifying female directors based on their financial background, the results show that earnings quality is significantly associated with female directors with relevant financial background. We do not find similar results for female directors without financial background, and therefore suggesting that results of prior studies are driven by female directors with financial background. Our results are robust after controlling for potential endogeneity concerns.

These findings have important implications for users of financial statements. In particular, users of financial statement should take into account female directors' background and the industries in which their firms operate. Furthermore, these results would provide important additional inputs to policy-makers in countries imposing a predetermined percentage of female representation on the boards of their corporations. In particular, regulators in these countries should consider the female directors' financial background when setting affirmative targets relating to gender representation on corporate boards.

This study, however, is subject to some limitations. In particular, although we provide some evidence on the role of female directors with financial expertise in enhancing earnings quality, our research design does not show the mechanism(s) that they use to improve earnings quality. Future research might investigate this research gap. In addition, ISS does not provide full data relating to the type of financial background, and therefore our analysis does not differentiate between accounting and non-accounting financial background. ${ }^{9}$ Finally, our sample only comprises US firms over the period 2007-2013, and it is not clear whether the current findings can be generalized to other countries or other time periods. Arguably, the participation of female directors on audit committees is increasing, and therefore, more up to date data would potentially enrich current knowledge of, and understanding about, the impact of female directors on earnings management in particular and other corporate outcomes in general. Therefore, future studies may offer new insights by conducting their analyses using firms from different contexts and countries, as well as over extended or different time periods.

\section{Appendix A}

See Table 14.

\footnotetext{
9 Arguably accounting background might have a more pronounced impact (Dhaliwal et al. 2010; Hsu, et al. 2018; Chen et al. 2020).
} 
Table 14 Variable definitions

Variables Operationalization

Dependant variable

ABS_DACC

Main independent variables

FDIR

FEMEX

FEMINEX

\section{Control variables}

MALEX

\section{ACSIZE}

IND

BIG4

SIZE

LEV

$\mathrm{OCF}$

ROA

MBV

LOSS

LNOA

TREM
Absolute value of discretionary accruals estimated using Eq. 1

The proportion of non-executive female directors on the audit committee to the total number of audit committee members

The proportion of non-executive female directors with relevant financial background on the audit committee to the total number of audit committee members

The proportion of non-executive female directors without financial background on the audit committee to the total number of audit committee members

The proportion of non-executive male directors with relevant financial background on the audit committee to the total number of audit committee members

The total number of audit committee members

The proportion of independent directors to the total number of directors on the board

Indicator variable taking the value of one if the external auditors is one of the big 4 audit firms and zero otherwise

The natural logarithm of firms' market capitalization

The proportion of long-term debt to total book value of common equity

Cash flows from operations scaled by lagged total assets

Net income before extraordinary items divided by lagged total assets

The proportion of firms' market capitalization to book value of common equity

Indicator variable set to one if net income before extraordinary items is a loss, and zero otherwise

Lagged net operating assets measured as net operating assets divided by sales. Net operating assets is the difference between operating assets and operating liabilities. Operating assets is calculated as total assets less cash and short-term investment. Operating liabilities is calculated as total assets less total debt, less book value of common and preferred equity, and less non-controlling interests

Total real earning management measured as abnormal production cost $+(-1) \times$ abnormal cash flows $+(-1) \times$ abnormal discretionary expenses. We calculate abnormal production cost as the residuals from the following model;

$$
\begin{aligned}
\text { PROD }_{t} / A T_{t-1}= & \beta_{0}+\beta_{1} 1 / A T_{t-1}+\mathrm{B}_{2} \text { SALES }_{t} / A T_{t-1} \\
& +\beta_{3} \Delta S A L E S_{t} / A T_{t-1}+\beta_{4} \Delta S A L E S_{t-1} / A T_{t-1}+e_{i t}, \text { where }
\end{aligned}
$$

$P R O D$ is the sum of cost of goods sold and change in inventory. AT is total

assets; SALES is sales and $\triangle$ SALES is change in sales

Abnormal cash flows are the residuals from the following model;

$O C F_{t} / A T_{t-1}=\beta_{0}+\beta_{1} 1 / A T_{t-1}$

operating cash flows

$$
+\beta_{2} S A L E S_{t} / A T_{t-1}+\beta_{3} \Delta S A L E S_{t} / A T_{t-1}+e_{i t} \text { where OCF is }
$$

Abnormal discretionary expenses are the residuals from the following model $D I S E X_{t} / A T_{t-1}=\beta_{0}+\beta_{1} 1 / A T_{t-1}+\beta_{2} S A L E S T / A T_{t-1}+e_{i t}$, where DISEX is as the sum of selling, general and administrative, $R \& D$ and advertising expenses. We set R\&D and advertising expenses to zero if they are missing. These three expectation models estimated using at least 20 industry-year observations 
Table 14 (continued)

\begin{tabular}{|c|c|}
\hline Variables & Operationalization \\
\hline \multicolumn{2}{|l|}{ Moderating attributes } \\
\hline FEMEX_OUT & $\begin{array}{l}\text { The proportion of non-executive female directors with relevant financial } \\
\text { background and serve on at least three outside public boards to the total } \\
\text { number of audit committee members }\end{array}$ \\
\hline FEMEX_LESS_OUT & $\begin{array}{l}\text { The proportion of non-executive female directors with relevant financial } \\
\text { background and serve on less than three outside public boards to the total } \\
\text { number of audit committee members }\end{array}$ \\
\hline FEMINEX_OUT & $\begin{array}{l}\text { The proportion of non-executive female directors without relevant financial } \\
\text { background and serve on at least three outside public boards to the total } \\
\text { number of audit committee members }\end{array}$ \\
\hline FEMINEX_LESS_OUT & $\begin{array}{l}\text { The proportion of non-executive female directors without relevant financial } \\
\text { background and serve on less than three outside public boards to the total } \\
\text { number of audit committee members }\end{array}$ \\
\hline FEMEX_LONG_TEN & $\begin{array}{l}\text { The proportion of non-executive female directors with relevant financial } \\
\text { background and long tenure to the total number of audit committee mem- } \\
\text { bers }\end{array}$ \\
\hline FEMEX_SHORT_TEN & $\begin{array}{l}\text { The percentage of non-executive female directors with relevant financial } \\
\text { background and short tenure to the total number of audit committee mem- } \\
\text { bers }\end{array}$ \\
\hline FEMINEX_LONG_TEN & $\begin{array}{l}\text { The percentage of non-executive female directors without relevant financial } \\
\text { background and with long tenure to the total number of audit committee } \\
\text { members }\end{array}$ \\
\hline FEMINEX_SHORT_TEN & $\begin{array}{l}\text { The percentage of non-executive female directors without relevant financial } \\
\text { background and with short tenure to the total number of audit committee } \\
\text { members }\end{array}$ \\
\hline \multicolumn{2}{|c|}{ Variables used to control for endogeneity } \\
\hline FEMALE_INDUTRY & The percentage of female directors within each two-digit SIC industry \\
\hline WO_EX_to_ME_EX & $\begin{array}{l}\text { The percentage of female directors possessing relevant financial background } \\
\text { to male directors possessing relevant financial background within each two- } \\
\text { digit SIC industry }\end{array}$ \\
\hline INV_MILLIS & $\begin{array}{l}\text { Inverse Mills ratio from a Probit model capturing the probability of hiring } \\
\text { female directors into audit committees }\end{array}$ \\
\hline
\end{tabular}

Open Access This article is licensed under a Creative Commons Attribution 4.0 International License, which permits use, sharing, adaptation, distribution and reproduction in any medium or format, as long as you give appropriate credit to the original author(s) and the source, provide a link to the Creative Commons licence, and indicate if changes were made. The images or other third party material in this article are included in the article's Creative Commons licence, unless indicated otherwise in a credit line to the material. If material is not included in the article's Creative Commons licence and your intended use is not permitted by statutory regulation or exceeds the permitted use, you will need to obtain permission directly from the copyright holder. To view a copy of this licence, visit http://creativecommons.org/licenses/by/4.0/.

\section{References}

Abbott LJ, Parker S, Peters GF (2004) Audit committee characteristics and restatements. Audit J Pract Theory 23(1):69-87

Adams R, Ferreira D (2004) Diversity and incentives in teams: evidence from corporate boards. Working Paper. Stockholm School of Economics

Adams R, Ferreira D (2007) A theory of friendly boards. J Financ 62:217-250 
Adams R, Ferreira D (2009) Women in the boardroom and their impact on governance and performance. J Financ Econ 94(2):291-309

Al Lawati H, Hussainey K, Sagitova R (2021) Disclosure quality vis-à-vis disclosure quantity: does audit committee matter in Omani financial institutions. Rev Quant Financ Account Forthcoming: 1-38

Aldefer SP (1986) The invisible directors on corporate boards. Harv Bus Rev 64(6):38-50

Armstrong CS, Blouin JL, Jagolinzer AD, Larcker DF (2015) Corporate governance, incentives, and tax avoidance. J Account Econ 60(1):1-17

Arthur N, Tang Q, Lin ZS (2015) Corporate accruals quality during the 2008-2010 Global Financial Crisis. J Int Account Audit Tax 25:1-15

Badertscher BA, Collins DW, Lys TZ (2012) Discretionary accounting choices and the predictive ability of accruals with respect to future cash flows. J Account Econ 53(1-2):330-352

Badolato PG, Donelson DC, Ege M (2014) Audit committee financial expertise and earnings management: the role of status. J Account Econ 58(2-3):208-230

Baik B, Choi S, Farber DB (2020) Managerial ability and income smoothing. Account Rev 95(4):1-22

Barth ME, Elliott JA, Finn MW (1999) Market rewards associated with patterns of increasing earnings. J Account Res 37(2):387-413

Bear S, Rahman N, Post C (2010) The impact of board diversity and gender composition on corporate social responsibility and firm reputation. J Bus Ethics 97(2):207-221

Beasley MS (1996) An empirical analysis of the relation between the board of director composition and financial statement fraud. Account Rev 71(4):443-465

Bedard J, Chtourou SM, Courteau L (2004) The effect of audit committee expertise, independence, and activity on aggressive earnings management. Audit J Pract Theory 23(2):13-35

Beekes W, Pope P, Youing S (2004) The link between earnings timeliness, earnings conservatism and board composition: evidence from the UK. Corp Gov Int Rev 12(1):47-59

Beneish MD, Vargus ME (2002) Insider trading, earnings quality, and accrual mispricing. Account Rev 77(4):755-791

Capezio A, Mavisakalyan A (2016) Women in the boardroom and fraud: evidence from Australia. Aust J Manag 41(4):719-734

Carter DA, Simkins BJ, Simpson WG (2003) Corporate governance, board diversity and firm value. Financ Rev 38(1):33-53

Catalyst Group (2004) The bottom line: connecting corporate performance and gender diversity. Research report sponsored by BMO Financial Group; Catalyst Publication Code D58; ISBN \#0-89584-244-0

Chen MC, Chang CW, Lee MC (2020) The effect of chief financial officers' accounting expertise on corporate tax avoidance: the role of compensation design. Rev Quant Financ Acc 54:273-296

Chizema A, Kamuriwo DS, Shinozawa Y (2015) Women on corporate boards around the world: triggers and barriers. Leadersh Quart 26:1051-1065

Cohen DA, Zarowin P (2010) Accrual-based and real earnings management activities around seasoned equity offerings. J Account Econ 50(1):2-19

Cohen DA, Dey A, Lys TZ (2008) Real and accrual-based earnings management in the pre-and post-Sarbanes-Oxley periods. Account Rev 83(3):757-787

Cumming D, Leung TY, Rui O (2015) Gender diversity and securities fraud. Acad Manag J 58(5):1572-1593

Daily CM, Dalton DR (2003) Women in the boardroom: a business imperative. J Bus Strateg 24(5):8-9

De Zoort F, Salterio S (2001) The effect of corporate governance experience and financial reporting and audit knowledge on audit committee members' judgements. Audit J Pract Theory 20(2):31-47

Dhaliwal DAN, Naiker VIC, Navissi F (2010) The association between accruals quality and the characteristics of accounting experts and mix of expertise on audit committees. Contemp Account Res 27(3):787-827

Eagly AH (2009) The his and hers of prosocial behaviour: an examination of the social psychology of gender. Am Psychol 64(8):644-658

Erhardt N, Werbel J, Shrader C (2003) Board of director diversity and firm financial performance. Corp Gov Int Rev 11(2):102-110

Faccio M, Marchica, MT, Mura R (2015) CEO gender, corporate risk-taking, and the efficiency of capital allocation. http://papers.ssrn.com/sol3/papers.cfm?abstract_id=2021136

Faleye O, Hoitash R, Hoitash U (2018) Industry expertise on corporate boards. Rev Quant Financ Acc 50(2):441-479

Fama EF, Jensen MC (1983) Separation of ownership and control. J Law Econ 26(2):301-325

Filip A, Raffournier B (2014) Financial crisis and earnings management: the European evidence. Int J Account 49(4):455-478 
Francis J, LaFond R, Olsson PM, Schipper K (2004) Costs of equity and earnings attributes. Account Rev 79(4):967-1010

Francis BB, Hasan I, Wu Q, Yan M (2014) Are female CFOs less tax aggressive? Evidence from tax aggressiveness. J Am Tax Assoc 36(2):171-202

Francis B, Hasan I, Li L (2016) Abnormal real operations, real earnings management, and subsequent crashes in stock prices. Rev Quant Financ Acc 46(2):217-260

Gul FA, Srinidhi B, Ng AC (2011) Does board gender diversity improve the informativeness of stock prices? J Account Econ 51(3):314-338

Gul FA, Hutchinson M, Lai KM (2013) Gender-diverse boards and properties of analyst earnings forecasts. Account Horiz 27(3):511-538

Harris O, Karl JB, Lawrence E (2019) CEO compensation and earnings management: does gender really matters? J Bus Res 98:1-14

Heckman JJ (1976) The common structure of statistical models of truncation, sample selection and limited dependent variables and a simple estimator for such models. Ann Econ Soc Meas 5(4):475-492

Helland E (2006) Reputational penalties and the merits of class-action securities litigation. J Law Econ 49(2):365-395

Hsu PH, Moore JA, Neubaum DO (2018) Tax avoidance, financial experts on the audit committee, and business strategy. J Bus Financ Acc 45(9-10):1293-1321

Huang J, Kisgen DJ (2013) Gender and corporate finance: are male executives overconfident relative to female executives. J Financ Econ 108(3):822-839

Huse M, Solberg A (2006) Gender related boardroom dynamics: how women make and can make contributions on corporate boards. Women Manag Rev 21(2):113-130

Ibrahim N, Angelidis J, Tomic IM (2009) Managers' attitudes toward codes of ethics: are there gender difference? J Bus Ethics 90:343-353

Jiang J (2008) Beating earnings benchmarks and the cost of debt. Account Rev 83(2):377-416

Jones J (1991) Earnings management during import relief investigations. J Account Res 29(2):193-228

Kalbers L, Fogarty T (1993) Audit committee effectiveness: an empirical investigation of the contribution of power. Audit J Pract Theory 12(1):24-49

Kao EH, Huang HC, Fung HG, Liu X (2020) Co-opted directors, gender diversity, and crash risk: evidence from China. Rev Quant Financ Account 55:461-500

Khlif H, Achek I (2017) Gender in accounting research: a review. Manag Audit J 32(6):627-655

Kirsch A (2018) The gender composition of corporate boards: a review and research agenda. Leadersh Quart 29:346-364

Kohlberg L (1984) Moral stages and moralization: the cognitive-development approach. In Kohlberg L (Ed), Essays on moral development, vol 2. The psychology of moral development: the nature and validity of moral stages: 170-2015. Harper and Row, San Francisco

Labelle R, Gargouri R, Francoeur C (2010) Ethics, diversity management, and financial reporting quality. J Bus Ethics 93(2):335-353

Lara JMG, Osma BG, Mora A, Scapin M (2017) The monitoring role of female directors over accounting quality. J Corp Finan 45:651-668

Li J, Mangena M, Pike R (2012) The effect of audit committee characteristics on intellectual capital disclosure. Br Account Rev 44(2):98-110

Liu M (2020) Real and accrual-based earnings management in the pre-and post-engagement partner signature requirement periods in the United Kingdom. Rev Quant Financ Acc 54(3):1133-1161

Liu Y, Wei Z, Xie F (2016) CFO gender and earnings management: evidence from China. Rev Quant Financ Acc 46(4):881-905

Lund DB (2008) Gender differences in ethics judgment of marketing professionals in the United States. J Bus Ethics 77(4):501-515

Mangena M, Pike R (2005) The effect of audit committee shareholding, financial expertise and size on interim financial disclosures. Account Bus Res 35(4):327-349

Martin A, Nishikawa T, Williams M (2009) CEO gender: effects on valuation and risk. Q J Financ Acc 48(3):23-40

McNichols M (2002) Discussion of the quality of accruals and earnings: the role of accrual estimation errors. Account Rev 77:61-69

Nguyen H, Ntim CG, Malagila J (2020) Women on corporate boards and financial and non-financial performance: a systematic literature review and future research agenda. Int Rev Financ Anal 71:101554

Osma BG (2008) Board independence and real earnings management: the case of R\&D expenditure. Corp Gov Int Rev 16(2):116-131

Owhoso V (2002) Mitigating gender-specific superior ethical sensitivity when assessing likelihood of fraud risk. J Manag Issues 14(3):360-374 
Powell M, Ansic D (1997) Gender differences in risk behaviour in financial decision-making: an experimental analysis. J Econ Psychol 18(6):605-628

Rose C (2007) Does female board representation influence firm performance? The Danish evidence. Corp Gov Int Rev 15(2):404-413

Roychowdhury S (2006) Earnings management through real activities manipulation. J Account Econ 42(3):335-370

Sarin R, Wieland A (2016) Risk aversion for decisions under uncertainty: are there gender differences? J Behav Exp Econ 60:1-8

Sharma VD, Iselin ER (2012) The association between audit committee multiple-directorships, tenure, and financial misstatements. Audit J Pract Theory 31(3):149-175

Simga-Mugan C, Daly BA, Onkal D, Kavut L (2005) The influence of nationality and gender on ethical sensitivity: an application of the issue-contingent model. J Bus Ethics 57(2):139-159

Singh H, Harianto F (1989) Management-board relationships, takeover risk, and the adoption of golden parachutes. Acad Manag J 32(1):7-24

Sloan RG (1996) Do stock prices fully reflect information in accruals and cash flows about future earnings? Acc Rev 71(3):289-315

Srinidhi B, Gul FA, Tsui J (2011) Female directors and earnings quality. Contemp Account Res 28(5):1610-1644

Stephenson C (2004) Leveraging diversity to maximum advantage: the business case for appointing more women to boards. Ivey Bus J 69(1):4-9

Sun J, Cahan S (2009) The effect of compensation committee quality on the association between CEO cash compensation and accounting performance. Corp Gov Int Rev 17(2):193-207

Sun J, Cahan SF, Emanuel D (2009) Compensation committee governance quality, chief executive officer stock option grants, and future firm performance. J Bank Financ 33(8):1507-1519

Sun J, Liu G, Lan G (2011) Does female directorship on independent audit committees constrain earnings management? J Bus Ethics 99(3):369-382

Tang CH, Lee YH, Lee MC, Huang YL (2020) CEO characteristics enhancing the impact of CEO overconfidence on firm value after mergers and acquisitions - a case study in China. Rev Pac Basin Financ Mark Policies 23(1):2050003

Terjesen S, Sealy R (2016) Board gender quotas: exploring ethical tensions from a multi-theoretical perspective. Bus Ethics Q 18(2):153-190

Terjesen S, Sealy R, Singh V (2009) Women directors on corporate boards: a review and research agenda. Corp Gov Int Rev 17(3):320-337

Trombetta M, Imperatore C (2014) The dynamic of financial crises and its non-monotonic effects on earnings quality. J Account Public Policy 33(3):205-232

Trueman B, Titman S (1988) An explanation for accounting income smoothing. J Account Res 26(Supplement):127-139

Tucker JW, Zarowin PA (2006) Does income smoothing improve earnings informativeness? Account Rev 81(1):251-270

Valenti A (2008) The Sarbanes-Oxley Act of 2002: Has It Brought About Changes in the Boards of Large U. S. Corporations? Journal of Business Ethics 81(2): 401-412.

Wang Y, Clift B (2009) Is there a "business case" for board diversity? Pac Account Rev 21(2):88-103

Williams RJ (2003) Women on corporate boards of directors and their influence on corporate philanthropy. J Bus Ethics 42(1):1-10

Xie H (2001) The mispricing of abnormal accruals. Account Rev 76(3):357-373

Xie B, Davidson WN, DaDalt PJ (2003) Earnings management and corporate governance: the role of board and the audit committee. J Corp Finan 9(3):295-316

Yang JS, Krishnan J (2005) Audit committees and quarterly earnings management. Int J Audit 9(3):201-219

Zalata A, Roberts C (2016) Internal corporate governance and classification shifting practices: an analysis of UK corporate behavior. J Acc Audit Financ 31(1):51-78

Zalata AM, Ntim C, Aboud GE, Gyapong E (2019a) Female CEOs and core earnings quality: new evidence on the ethics versus risk-aversion puzzle. J Bus Ethics 160(2):515-534

Zalata AM, Ntim CG, Choudhry T, Hassanein A, Elzahar H (2019b) Female directors and managerial opportunism: monitoring versus advisory female directors. Leadersh Q 30(5):101309

Zhang Y, Zhou J, Zhou N (2007) Audit committee quality, auditor independence, and internal control weaknesses. J Account Public Policy 26(3):300-327

Publisher's Note Springer Nature remains neutral with regard to jurisdictional claims in published maps and institutional affiliations. 